\title{
WHAT REALLY HAPPENED IN RAVENNA? C.G. JUNG AND TONI WOLFF'S MOSAIC VISION
}

RONALD V. HUGGINS

$P H A N E S$ • VOLUME $3 \cdot 2020$ • PP. 76-115

https://doi.org/10.32724/phanes.2020.Huggins 


\begin{abstract}
On at least five different occasions, C.G. Jung told the story of how he and Toni Wolff saw and discussed four mosaics in an ancient Baptistery in Ravenna, Italy, that turned out not to exist, but rather had apparently represented some sort of shared visionary experience. It was, Jung said, 'among the most curious events in my life' (MDR:285). This article begins by establishing the correct date and location of this incident. Then it seeks to show, with the aid of the author's onsite investigation of the relevant sites in Ravenna, that what Jung and Wolff saw in the Baptistery actually did exist but was partly misremembered and partly misinterpreted. Pictures are included that illustrate relevant details.
\end{abstract}

\title{
KEYWORDS
}

Jung Chronology, Toni Wolff, Ravenna, Baptistery of the Orthodox, Arian Baptistery, San Giovanni Evangelista. 


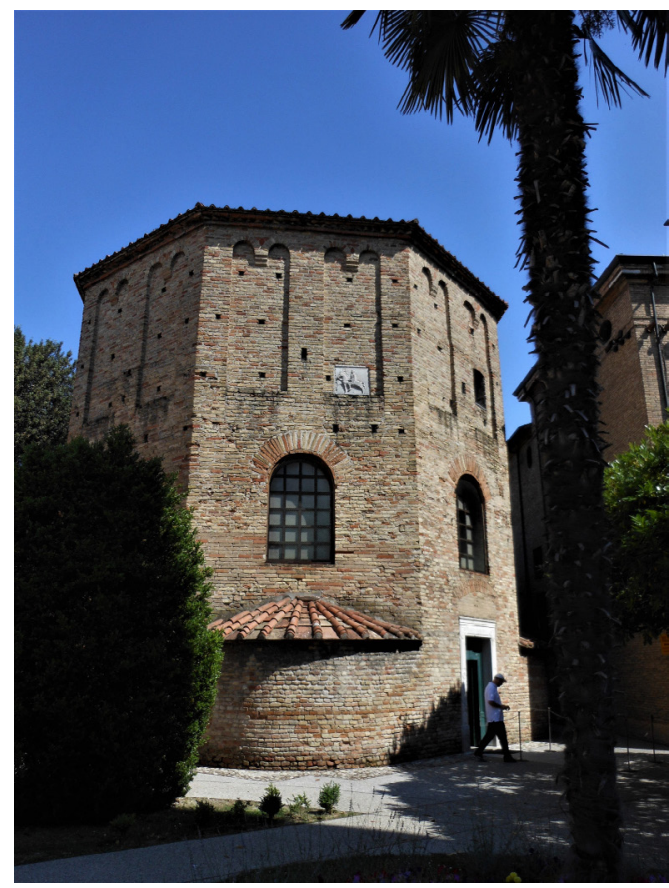

Fig. 1: Ravenna's Baptistery of the Orthodox* $\mathrm{n}$ 1932, C.G. Jung
and Toni Wolff, while
visiting Ravenna's
Baptistery of the

Orthodox, had an experience that Jung later described as 'among the most curious events in my life' (Jung \& Jaffé 1965 [henceforth $M D R]: 285){ }^{1}$ They saw what they took to be four early Christian mosaics. Jung had talked about the meaning of these mosaics at some length while Toni Wolff looked on and listened. Not long afterwards, however, they were informed that the mosaics they thought they saw did not exist. Jung spoke of the experience on at least five different occasions, in

1932, 1948, twice in 1957 , and $1948 .^{2}$ One of the 1957 accounts became the source from which was developed the version of the story now found in Jung's posthumous 'autobiography,' Memories, Dreams, Reflections (=MDR:284-287). For Jung the experience represented a watershed moment in the development of his thought: 'Since my experience in the baptistery in Ravenna, I know with certainty that something interior can seem to be exterior, and that something exterior can appear to be interior.

\footnotetext{
${ }^{*}$ All photographs taken by the author.

${ }^{1}$ For another study of the Ravenna mosaic vision from a psychological perspective, see Noel (1993:159-163).

212 October 1932 (Jung 1932a:16), June 1948 (Harding 1948:184-185), 9 Jan 1957 (Bennet 1985:80-81), and 3 August 1957 (Protocols [=Prot.] A.127-28, B.46-47, F.62122), and 5 May 1948 (Max Knoll to Cary F. Baynes, 19 Jul 1959, henceforth Knoll). Thanks to Sonu Shamdasani for kindly introducing me to and providing me with a copy of the Knoll account. 'Protocols' is the name given a collection of documents that consist primarily of the interview notes Aniela Jaffé took of conversations with C.G. Jung to use as the basis for Memories, Dreams, Reflections. The portion discussing the Ravenna incident represents three drafts of the same 3 August 1957 interview. The priority of Prot. A.127-129, which I always list first when citing the Protocols, is obvious from the number of proof-reading marks and other hand-written corrections in its margins and between its lines that are incorporated into the main texts of the other two drafts.
} 
The actual walls of the baptistery, though they must have been seen by my physical eyes, were covered over by a vision of some altogether different sight which was as completely real as the unchanged baptismal font' (MDR:287). Although the $M D R$ version is the most familiar one, E.A. Bennet's account, also from 1957, is the most complete. Here it is in its entirety:

C.G. had spoken to Toni Wolff about the Baptistry of the Orthodox in Ravenna where Galla Placidia was buried. Early in the fifth century, after surviving a stormy sea voyage to Ravenna, she had built a church there in fulfillment of a vow. The original church was later destroyed, but her tomb is there.

After visiting the tomb they entered the Baptistry. It was filled with a bluish light, though there was no artificial lighting. C.G. looked round the building and remarked to Toni, 'Isn't it curious? Here are these beautiful mosaics on the west, the east, the south and the north in this octagonal building, and I can't remember seeing them before - it's most remarkable for they are so striking!' In the centre was the font; it was big for it was used for immersion. For twenty minutes they studied the mosaics. C.G. described them as about twice the size of a tapestry hanging on the verandah (which is about six feet by eight feet). Each depicted a baptism scene: one of St. Peter sinking into the sea and our Lord saving him; one of the Israelites in the Red Sea, when the water drowned the Egyptians; one of Naaman the Syrian bathing in the water and being cured of leprosy; and one of our Lord's baptism.

The double symbolism of baptism as a saving of life and as a danger of death was shown in each mosaic. C.G. was particularly impressed by that showing Peter sinking in the sea and stretching out his hand and Jesus reaching for him, this was a most beautiful mosaic of lapis lazuli.

On leaving the Baptistry they went to a shop opposite to get photographs of these mosaics - one of the small shops always found near such places. They offered pictures of the Baptistry, but none of the mosaics. They went to another shop-no luckand to several others, but they could not find the photographs they wanted.

Soon after C.A. Meier was going to Italy and C.G. told him to be sure to visit Ravenna and see these mosaics and get pictures 
of them, or if he couldn't to take photographs. Meanwhile C.G. was giving a seminar in the course of which he mentioned the wonderful mosaics he and Miss Wolff had seen in Ravenna, and he described them in detail.

When Dr. Meier returned from Italy he told C.G. that he had gone to the Baptistry in Ravenna but that there were no mosaics there of the kind he had described. C.G. told this to Toni Wolff who said, 'That's ridiculous, I saw them with my own eyes and you talked of them for about twenty minutes!' 'Nevertheless,' he said, 'there are no such mosaics.' So at the seminar he said, 'Ladies and gentlemen, I'm sorry but there are no mosaics'. (Bennet 1985:80-81).

To this account $M D R$ adds in addition Jung's recollection that on his previous visit to the Baptistery there had been windows, which were now covered over by the mosaics (184). He also identifies the church that "was later destroyed' in Bennet's account, as San Giovanni Evangelista, and says that it, 'together with its mosaics, was destroyed by fire' in the 'early Middle Ages' (286).

Also included in $M D R$ is a footnote by Aniela Jaffé informing us that Jung 'explained the vision as a momentary new creation by the unconscious (eine momentane Neuschöpfung des Unbewussten), arising out of his thoughts about archetypal initiation. The immediate cause of the concretization lay, in his opinion, in a projection of his anima upon Galla Placidia' (286, n. 6; Jung \& Jaffé 2013 [henceforth ETG]:314, n. 10). Perhaps a better English word to bring across the sense of what Jung appears to have meant by Neuschöpfung would be 're-creation' rather than 'new creation,' since Jung seems to have had in mind that the mosaics he and Toni Wolff saw in the Baptistery of the Orthodox were actually visionary restorations of four, long-destroyed mosaics from the basilica of San Giovanni Evangelista. ${ }^{3}$

Marie-Louise von Franz saw in the Ravenna incident a striking parallel to the strange experience of C.A.E. Moberly and E.F. Jourdain, who reported visiting Petit Trianon in 1901 and being transported back to the eighteenth-century 'Versailles of Marie Antoinette,' where, 'they had not only seen people of that time but buildings which no longer

${ }^{3}$ For the view that what Jung and his acquaintance saw were actually long-destroyed mosaics from Galla Placidia's Church of San Giovanni Evangelista miraculously re-created (a view only hinted at in Jung's accounts), see, for example, Marie-Louise von Franz (1992:115), Maggy Anthony (1990:32), Molton \& Sikes (2011:6), Tilander (1991:121), and McLynn (1996:318-319). 
existed, including having passed a little bridge which had disappeared since' (von Franz 1992:115). However, when one peruses Moberly and Jourdain's book, An Adventure (1913), one immediately observes the striking difference in how they responded to their remarkably mysterious experience as compared to how Jung did. Moberly and Jourdain engaged in what von Franz rightly described as 'years of painstaking research' to determine whether what they saw in the past had really existed in the eighteenth century as they had experienced it. In contrast, so far as we know, it never seems to have occurred to Jung to return to Ravenna himself to try to make sense of what had happened there.

Our central purpose here, then, is to explore what Jung might have discovered had he returned to Ravenna to investigate the matter. We shall suggest an account of what occurred that appears to provide a very straightforward solution: What Jung and Toni Wolff saw was really there, but not precisely as Jung had described it. This, we shall argue, was due partly to Jung's misremembering and partly to his misinterpreting what he saw. Then, afterward, when C.A. Meier visited the baptistery later looking for the mosaics, the description Jung had given him caused him to miss the obvious solution, just as this author, with the same expectations informing him, missed it as well on his first visit to the baptistery.

\section{SORTING OUT THE ACCOUNTS}

So far as I have been able to discover, Jung never left an account of the Ravenna incident in his own hand. All are based on notes taken down by others. All these accounts differ to one degree or another, even on questions as basic as where and when the event actually occurred. The problem has been further magnified - sometimes understandably, other times quite inexplicably - by the reconstructions of the event in biographies of Jung and other secondary literature about him. As a result, there is at present no consensus in the literature as to when the event took place, with proposed dates differing by more than twenty years. This is remarkable since the evidence relating to the matter is actually quite straightforward and definitive, but it is the situation none the less. Furthermore, accounts deriving from Jung himself point to two competing locations as to where the vision occurred. As a result, before we can address the issue of what Jung and Toni Wolff saw, we must first try to settle the matter of when and where they saw it. 


\section{WHEN?}

So far as we know, Jung visited Ravenna only twice, once in 1914 on a bike trip with his friend and colleague Hans Schmid-Guisan, and once in 1932 with Toni Wolff. MDR is correct in indicating there were only two visits to Ravenna, but incorrect in placing those visits in 1913 and 'twenty years later,' or 1933 (MDR:284). Both dates, however, are only a year off.

How it came about that these dates were included in $M D R$ is a mystery. Neither of them are supported in any of the drafts of Aniela Jaffe's report of her 3 August 1957 interview with Jung that served as the basis for the $M D R$ version. In that interview Jung correctly remembered 1932 as the date of his trip to Ravenna with Toni Wolff (who is explicitly mentioned) during which the Ravenna vision occurred. (Protocols [henceforth, Prot.] A.127, cf. B.46, F.621). ${ }^{4}$ Jung also correctly identifies 'Dr. Schmid' as his traveling companion on his previous trip there (Prot. A.129, cf. B.48, F. 623). ${ }^{5}$ However, he incorrectly recalls, or else Aniela Jaffé incorrectly reports, the first trip's taking place ' 8 Jahre zuvor' the second, that is to say, in 1924.

Despite the fact that Jung speaks in the first person throughout $M D R$, he wrote only three chapters for the book, with the rest being mainly the work of Aniela Jaffé. ${ }^{6}$ By the time the book was finished things had

\footnotetext{
${ }^{4}$ In the original draft, Jung names his companion on the second trip as 'Frl. Wolff,' which is marked out and replaced with 'T.W.' (A.127 and 128). The correction is added to the two later copies (B.46 and 48, F. 621 and 623).

${ }^{5} M D R$ doesn't specify who accompanied Jung on either trip.

${ }^{6}$ A document signed by Jung himself reads: 'Aniela Jaffé is the author of a book entitled "Gedanken, Erinnerungen, Träume von C.G. Jung" [i.e., MDR] written in the form of an autobiography of C.G. Jung, to which C.G. Jung has contributed three chapters, written by himself $[. .$.$] The chapters [...] were to be considered as$ his contributions to the work of Mrs. A. Jaffé. The book was to be published in the name of Mrs. Jaffé and not in the name of C.G. Jung, because it did not represent an autobiography composed by C.G. Jung [...] On [sic] a conference held on the 26th August 1960 [...] C.G. Jung confirmed again that he did strictly consider this book as an undertaking of Mrs. A. Jaffé to which he had only given his contributions. Therefore the book was not to be included in his Collected Works.' ('Resolution of the Editorial Committee for “The Collected Works" of Prof. C.G. Jung [29 Nov 1960],' 1-2; The Records of the Bollingen Foundation, Bx 102, Fd XX add. 'Jaffé, Memories, Dreams, Reflections,' Manuscript Department, Library of Congress, Washington, DC [henceforth MD,LOC]. In other contexts, Jung spoke of the project as his own. On 21 March 1959, for example, he told E.A. Bennet that for the previous two years (at least) he had been 'writing an autobiography,' but that 'he was hesitant to publish it because it could so
} 
become more complicated, effectively reducing Jung's direct involvement in the project even further. ${ }^{7} M D R$ was never comprehensively reviewed and corrected by Jung, nor did he ever see the manuscript in its final form, much less 'authorize' it. ${ }^{8}$

Consequently when evaluating details such as this in $M D R$ or Jaffe's manuscripts underlying it (the Protocols), it is important to keep in mind the procedure used to produce them. According to Jaffé, the recording of the original interviews was not a matter of Jung's in any sense dictating his story to her, nor was a recording machine used. As Jaffé herself insisted, 'Jung never dictated one single sentence of this book [i.e., of $M D R$ ]' (Aniela Jaffé to H. S. Bailey of Princeton University Press, 3 Jan 1984, WMcGP, Bx 50, Fd 9, MD,LOC). The material was gathered in a relatively informal way. As Jaffé recalled, Jung 'spoke and followed a sort of Freudian line of associations,' after which, 'When I came home, I took a cup of tea, went immediately to the typewriter: copied my notes and filled them out with [what] was still in my ears [...] out of these puzzle-pieces I had to make one whole story' (Aniela Jaffé to William McGuire, 26 Nov 1981. WMcGP, Bx 44, Fd 10, MD,LOC. Letter included on the microfilm copy of the Papers of C.G. Jung, MSS 21,057, MD,LOC). Jaffé also tells us in another place that 'Jung never read them [i.e., the Protocols]' (Aniela Jaffé draft statement to the Library of Congress 'Concerning to the origin of the Protocols [Aug 1983],' WMcGP Bx 50, Fd 9. MD,LOC).

Despite the fact that the current edition of $M D R$ continues to give 1913 as the date of Jung's first visit to Ravenna, it has been known for

easily be misunderstood, and this could disturb many people who depended upon him' (Bennet 1985:106). Jaffé began work on the Protocols in 1957 (Aniela Jaffé's draft statement to the Library of Congress 'Concerning to the origin of the Protocols [Aug 1983],' William McGuire Papers [henceforth WMcGP], Bx 50, Fd 9, MD,LOC).

${ }^{7}$ Regarding the remark about Jung's writing three chapters of $M D R$, Sonu Shamdasani writes: 'it is actually more complicated. The first three chapters represent an amalgam of Jung's 1958 memoir + material from the protocols. Some bits of the memoir were deleted. The section on the [P] ueblo [I]ndians is an excerpt from Jung's ms. on this, and Jung wrote the "late thoughts" chapter - the original of which hasn't yet come to light' (Shamdasani to the author, 16 Jun 2020).

${ }^{8}$ As Shamdasani writes: 'In her introduction, Jaffé claims that Jung "read through the manuscript of the [=this] book and approved it" [MDR:vii / ETG:9]. However, this simply could not have been the case, as Jung never saw the final manuscript' (2005:29). Furthermore, even before that, as Thomas Fischer notes, Jung 'was up in age and easily tired [...] [and] no longer had the stamina to bother about such details as checking dates and wording' (Fischer to the author, 3 Jul 2020). For an overview of the complicated editorial process that gave birth to $M D R$, see Shamdasani 2005:15-45. 
quite a long time that the correct date is 1914. The date has already been corrected, for example, in Erinnerungen, Träume, Gedanken (henceforth ETG), the German edition of MDR (ETG:312). ${ }^{9}$ Also, in 1975, Jung's son Franz complained that he'd informed Jaffé 'some years ago' about the incorrect date, noting that postcards to Emma proved 'that C.G. was on the 7.4.1914 [7 April 1914] the first time in Ravenna' (Franz Jung to William McGuire, 25 Feb 1975, WMcGP, Bx 3, Fd 3, MD,LOC). ${ }^{10}$ Franz's date appears to be based on a postcard sent from Bologna, Italy, on 5 April 1914 in which Jung tells Emma: 'tomorrow we [he and SchmidGuisan] will head to Ravenna'. Jung perhaps wrote the postcard on the evening of 4 April 1914, and posted it on the morning of the fifth as he and Schmid-Guisan were starting out on their bicycles for nearby Ravenna. ${ }^{11}$

But although many now accept the 1914 date for Jung's first visit to Ravenna, a surprising number of writers astonishingly name not SchmidGuisan as his companion on that journey, but Toni Wolff (Bair 2003:248; Healy 2017:124; Lachman 2010:129; Mehrtens 2012:71; Owen 2015:46; Clark-Stern 2010:25-26). The implication is that the mosaic vision took place on the 1914 visit as well, which Bair clearly implies (cf. 248,729, n. 34) ${ }^{12}$

\footnotetext{
${ }^{9}$ However, the German edition did not also adjust the reference to the second trip's occurring 20 years after the first. As a result, it points to 1934 as the date of the second visit, which, as we shall see, is two years too late.

10 There is some question, however, whether Franz had earlier suggested 1912 as the correct date, rather than 1914. At least such might seem to be indicted in the Freud/ Jung Letters in a footnote to the 27 April 1912 letter of Jung to Freud (312 J:501). The note explains that the trip to Italy described in that letter 'was apparently also the occasion of Jung's first visit to Ravenna (information from Mr. Franz Jung, correcting the date 1913 in Memories, p. 284/265).'

11 That Franz Jung must have had this postcard in mind is confirmed by Thomas Fischer, Director of the Foundation of the Works of C.G. Jung, who kindly provided information about the 5 April postcard, including confirmation that Schmid-Guisan was Jung's traveling companion (Thomas Fischer to the author, 6 and 14 Mar and $1 \mathrm{Apr}$ 2019). Bair (2003:729-730) and Clay (2016:366), have previously sought and obtained this evidence based on family postcards for the April 1914 date. Clay includes the detail that 'the Jung family archive confirms it was Schmid.' However, both authors complicate matters by stating things in the context that are not correct, Bair saying that the postcard verified 'the correct date of his first (of three) visits to Ravenna,' there is only evidence for two visits, and Clay, that Jung commented in the postcard on the Ravenna mosaics, which he did not (Clay 2016:243).

${ }^{12}$ After telling the story of Jung and Wolff's alleged visit to Ravenna in 1914, Bair then informs her readers that this was the visit 'Described in $M D R$, chapter 9, sec. 5,' i.e., the section telling about the mosaic vision (Bair 2003:729, n. 34). Bair's description of the Protocols at this point is confused and inaccurate. She says that 'some' of the Protocols 'are dated August 3, 1957; others are left undated and unpaginated' and that 'he [Jung]
} 
and Healy states outright (2017:124-125).

Ultimately the evidence makes 1914 as the date of the mosaic vision all but impossible. The Protocols specifically identify 'Dr. Schmid' as the one who accompanied Jung on his earlier visit (Prot. A.129, cf. B.48, F.623). That Schmid-Guisan was indeed Jung's companion on that trip is confirmed as well by the previously mentioned 5 April 1914 postcard Jung sent to his wife Emma from Bologna. ${ }^{13}$ Yet even supposing that Wolff was in Ravenna as well when Jung and Schmid-Guisan arrived there in 1914, as Bair seems to suggest, the consistent details of the vision story as Jung repeatedly told it rule out the mosaic vision having taken place at that time, and places beyond reasonable doubt that Wolff was, in any case, also in Ravenna with Jung in 1932. It was then, and not before, that they experienced the mosaic vision together. And this for a number of reasons.

A key feature of the vision story as Jung told it was that it occurred on his second visit to Ravenna and that he was struck not only by the fact that he had no recollection of the mosaics being there before (Bennet 1985:80), but that he felt sure that on his first visit there had been windows where the mosaics now were (Prot. A.127, cf. B.46, F.621; MDR:284). In other words, part of the reason the vision was remarkable in the first place is that things seemed different from what they were before.

Even more decisive against a 1914 date for the vision, is the crucial role played by Carl Alfred Meier (1905-1995) in the story. A consistent feature in Jung's telling is that when he and Toni Wolff returned to Zurich he found that C.A. Meier was soon to travel to Ravenna himself, and so asked him to obtain pictures of the mosaics when he was there, which, as it turned out, Meier was unable to do. While Meier is referred to only as an 'acquaintance' in $M D R$ (285), other accounts specifically name him (Bennet 1985:81; Harding 1948:184; Prot. A.128, cf. B.47-48, F.62223). The impression as well is given that Meier's departure for Ravenna

states [...] that he had been in Ravenna once with "acquaintances" eight years earlier [...] In a later Protocol, he says the acquaintance was Dr. Hans Schmid, with whom he bicycled from Switzerland to Ravenna' (2003:730, n. 34). In fact, all of the accounts are paginated, and there is no disagreement between them on the matters Bair mentions. All three refer to Jung's being in Ravenna on his previous trip 'with acquaintances' (mit Bekannten) (A.127, cf. B.46, F.621) — set in the particular context in contrast with his companion on his second trip, namely, Toni Wolff - and all three identify SchmidGuisan as his traveling companion on the first trip (Ich war mit Dr. Schmid dort) (A.129, cf. B.48, F.623).

${ }^{13}$ Thomas Fischer to the author (2 May 2019): 'Schmid-Guisan is mentioned in the postcard. Carl mentions that Schmid also sends his greetings and that all goes well with the two of them'. This trip is mentioned in Jung 1932:760-761. 
occurred, as Bennet has it, 'soon after' Jung's return (Bennet 1985:81). In MDR Jung simply says that 'When I was back home, I asked an acquaintance who was going to Ravenna...' (285). The Protocols likewise say that Meier was traveling to Ravenna 'soon' (bald). ${ }^{14}$

Meier's role does not fit with an April 1914 date for the mosaic vision because it was on the $19^{\text {th }}$ of that very month that the young Carl Alfred Meier celebrated his ninth birthday!

Even supposing Jung misremembered its being Meier who went to Ravenna, that it had been somebody else who had returned from Ravenna in 1914 and informed him that the mosaics did not exist, it would make no difference, because Jung can be shown to still believe the mosaics did exist eighteen years later from his comments in the 1932 Kundalini Seminar. ${ }^{15}$

In contrast, when we accept the 1932 date for the mosaic vision given by Jung in the Protocols, all the evidential details snap into focus. In the various accounts where Jung tells of C.A. Meier's unsuccessful trip to Ravenna, he speaks about how in the meantime ${ }^{16}$ he had spoken about the mosaics as actually existing in a seminar, only to have to admit to the same group after hearing from Meier that they did not (Bennet 1985:81). ${ }^{17}$ The Protocols explicitly identify the seminar in question as the Kundalini Yoga Seminar, where, in the 12 October 1932 session, we actually find Jung speaking in a way that shows he is simply assuming the mosaics were real: 'if you study the beautiful mosaics in the Baptistery of the Orthodox in Ravenna (which dates from the fourth or the beginning of the fifth century [...] you see four scenes depicted...' (Jung 1932a:16). This would mean that even though Jung believed the mosaics existed on 12 October 1932,

14 ،...er reiste bald darauf ebenfalls nach Ravenna' (Prot. A.128, cf. B.47, F.622).

${ }^{15}$ When the question of publishing the notes from the 1932 Kundalini Seminar later arose, Jung wrote to R.F.C. Hull: 'There is one particular story which must be excluded, because it is entirely impossible, and that is the story of the baptismal symbolism in the Battistero de[gl]i Orthodossi [sic] in Ravenna' (Jung to Hull, 5 May 1954), WMcGP Bx 86, Fd 15, MD,LOC. Somehow Jung's instruction was not carried out, which turned out to be a positive thing in terms of the case developed here. Thanks to Sonu Shamdasani for calling my attention to this letter.

16 'Meanwhile' (Bennet 1985:81, MDR:285); 'Inzwischen' (ETG:313); But in the Protocols 'Unmittelbar nach meiner Rückkehr' (A.128, cf. B.47, F.622). Harding's account is confused. She says Meier went to Ravenna 'a year or two' after the seminar (1948:184), but then she misremembers the seminar as taking place in 1929 instead of 1932.

${ }^{17}$ A version of Wolff's response is also in $M D R$ (285), and was added by hand in the original draft of the Protocols account and then incorporated into the text of the later copies: Wir hatten sie ja beide ganz deutlich gesehen! (A.128, cf. B.48, F.623). So far as I have been able to discover all accounts of Wolff's reaction post-date her 1953 death. 
he no longer did by the time the last lecture in that series concluded on 2 November 1932.

The date fits as well the part played by Meier, who had replaced Helton Goodwin 'Peter' Baynes as Jung's assistant the previous year (Hannah 1991:204-205 [esp. n. n.]; Jansen 2003:238, 252-53), and who was actually present at the Kundalini Yoga Seminar, as was Toni Wolff (Jung 1932a:xiv).

All of this fits well a scenario that might have unfolded as follows: Meier hears Jung's description of the mosaics during the seminar, takes him aside between sessions and mentions what he had actually discovered in Ravenna, after which Jung has a word about it with Toni Wolff, who, according to Bennet, responded, 'That's ridiculous, I saw them with my own eyes and you talked of them for about twenty minutes!' (Bennet 1985:81). And then, when the seminar members had reconvened, Jung tells the whole group what he had just learned from Meier. ${ }^{18}$

\section{WHERE?}

Certain ambiguities in Jung's accounts of the mosaic vision have given scholars and Jung biographers false impressions as to the actual setting of the mosaic vision. From what Jung says, one might be led to believe that the long-destroyed basilica of San Giovanni, the tomb of Galla Placidia, and the Baptistery of the Orthodox were all part of a single building complex on a single site. As we read in Bennet's account: 'The original church was later destroyed, but her tomb is there. After visiting the tomb they entered the Baptistry' (1985:80). A similar impression of the near proximity of tomb and baptistery is given in MDR (284): 'we went directly from the tomb into the Baptistery of the Orthodox' (my italics). The potential confusion caused by these statements can be seen, for example, in McLynn's mistake in placing the Tomb of Galla Placida in the Church of San Giovanni (apparently forgetting Jung's claim that the church had been destroyed in the middle ages), and Kerr's apparently thinking the baptistery stands above the tomb when he speaks of how Jung and his companion 'meditated long on the stained-glass windows of the chapel above the tomb of Galla Placidia' (Kerr 1993:406). But, of course, Kerr did not get his reference to stained-glass windows from Jung, who never mentions such, nor from any trustworthy source. Neither the tomb nor the baptistery have (nor had) stain-glass windows. The windows of the

${ }^{18}$ No such statement of correction by Jung appears in the published notes of this seminar. 
tomb are made of thinly-sliced, caramel-coloured alabaster, and those of the baptistery, of plain glass (which may or may not have been opaque in 1932 as they are today). ${ }^{19}$

In the Spring of 1973 a five-page letter written on a small notepad arrived in the offices of Routledge \& Kegan Paul Ltd, London. The letter, dated 26 April, was entirely dedicted to pointing out what its author, a certain J. Fletcher of Essex, considered errors in the account of the mosaic vision in $M D R$. In the process of 'correcting' the account, however, Fletcher makes a number of errors in fact and logic himself. The first of his criticisms, however, was entirely just:

Dr Jung says [...] [']We went directly from the tomb [of Galla Placidia] into the Baptistry of the Orthodox[']. This statement is, I am sure, not correct because the Tomb of Galla Placidia is nowhere near the Baptistry of the Orthodox which lies the other side of the city (2 miles or so)!! one cannot go directly into one or the other. (J. Fletcher to [Routledge \& Kegan Paul, Ltd], 26 Apr [1973], 1-2. WMcGP Bx 3, Fd 3, MD,LOC).

Although the baptistery is not anything like two miles away from the tomb, it is in another part of the city, a considerable walk of many blocks amounting to a half a mile or so. And this truly does make the language of going directly from one to the other at the very least unusual. ${ }^{20}$

In his 15 May 1973 response, Norman Franklin, writing on behalf of the publisher, bemoaned the fact that 'the Editor concerned with the book did not bother to check Jung's memories [...] and he died about ten years ago,' making it impossible to correct. He did however suggest the possibility that the matter might be rectified in 'a future critical edition.' Franklin passed the letter on to William McGuire, who, in turn, sent it to Aniela Jaffé, at the same time writing to Fletcher as well explaining that $M D R$ was not part of Jung's Collected Works, and that it was Jaffé 'alone who decides on and approves changes in the text.' (William McGuire to J. Fletcher, 18 May 1973. WMcGP Bx 3, Fd 3, MD,LOC). McGuire suggested that, in his own view, 'Jung's apparent errors in

${ }^{19}$ On the alabaster widows, see E. Tileston's description of her visit to the Tomb of Galla Placidia on 27 April 1906 (Tileston 1915:110). For a view of the baptistery's windows at the turn of the last century, see Ricci (1900:[15]).

${ }^{20}$ Anschließend in the German edition (ETG:312), 'Dann gingen sie ins nahegelegene Baptisterium' (Knoll), Direkt in the Protocols, which give as the destination not the Orthodox but the Arian Baptistery (Prot. A.127, cf. B.46, F.621). But both baptisteries are a considerable distance from the Tomb of Galla Placidia. 
remembering (some 30 years later) the religious sites of Ravenna are of equal interest with his fantasy of the mosaics'. He also suggested that since Fletcher was apparently the first to take concete issue with $M D R$ 's account of the Ravenna incident, he might consider writing up a small article and submitting it to Spring Journal then edited by James Hillman, whose address McGuire passed along. And that is where the matter ended. And yet all the while a possible solution to the conundrum suggested itself in a part of the Protocols that never made it into $M D R$.

For Jung the memory of his going directly from the tomb of Galla Placidia to the Baptistery of the Orthodox played an important part in his explanation of the mosaics being a 'momentary new creation by the unconscious' whose 'immediate cause [...] lay [...] in a projection of his anima upon Galla Placidia' (MDR:286, n. 6). 'During a stormy crossing from Byzantium to Ravenna in the worst of winter,' explained $M D R$, 'she made a vow that if she came through safely, she would build a church and have the perils of the sea represented in it' (286). Similarly, in his 'confrontation with the anima,' Jung had also 'come close to drowning,' a connection which, as he suggested, might cast 'a certain light' on the mosaic vision (MDR:285). ${ }^{21}$ From this perspective Jung could have merely wanted to stress that the visit to the second site occurred soon enough after the first for Jung's intense feelings of connectedness with Galla Placidia to still be active and psychically effectual. But, in fact, there appears to have been more to it.

In $M D R$ we are told that upon leaving the Baptistery Jung went to Alinari to buy pictures, but found none. Given that time 'was pressing' since it 'was only a short visit,' he decided to postpone trying to obtain pictures until later (285). At this point in the Protocols, Jung explains that the reason time was pressing was that they still wanted to see San Vitale. The Tomb of Galla Placida is actually on the grounds of San Vitale, quite literally in its back yard, so that if you want to see it today you have to present your ticket at the San Vitale gate and approach the tomb either by walking around, or more conveniently, through San Vitale. ${ }^{22}$ So, if for some reason Jung and Wolff went from the tomb to the baptistery and

\footnotetext{
${ }^{21}$ The last point, about a certain light being cast on the vision by the connection is part of a paragraph not included in the Protocols.

${ }^{22}$ Nachdem wir das Baptisterium verlassen hatten, stürzte ich sogleich zu Alinari, um mir Photographien von den Mosaiken zu kaufen. Dort habe ich natürlich nichts gefunden. Ich habe auch davon Abstand genommen weiter zu suchen, weil die Zeit drängte. Wir wollten noch nach San Vitale. So habe ich mir diesen Einkauf aufgespart für später. Am andern Tag sind wir wieder abgereist, und ich bin nicht mehr dazu gekommen, noch einmal zu Alinari zu gehen (Prot. A.128, B.47, F. 622). Note that they did not even leave Ravenna the same day they visited the baptistery.
} 
then back to San Vitale, that would indeed represent an unusual departure from the usual itinerary for visiting those sites. In light of this, it seems perfectly natural for them to say they went 'directly' from the tomb to the baptistery, and only afterward back to San Vitale, rather than doing the more obvious thing of viewing the tomb and San Vitale together first and then going on to the baptistery. Perhaps since San Vitale is one of the most magnificent churches in Ravenna, they wanted to visit the baptistery first, since it was small, and then save San Vitale for last.

\section{DID JUNG MISREMEMBER WHERE THE MOSAIC VISION HAPPENED?}

Disparities in the accounts led the author to consider another possibility. What if Jung had gotten confused as to where he and Toni Wolff saw the mosaics? What if he had simply sent C.A. Meier to the wrong place, with the predictable result? What if the mosaics in question were to be found in some side chapel or alcove of one of Ravenna's other great, mosaic-clad UNESCO World Heritage ecclesiastical monuments: Sant' Apollinare Nuovo, Sant' Apollinare in Classe, ${ }^{23}$ San Vitale, the Arian Baptistery, the Archiepiscopal Chapel, or the Tomb of Galla Placidia itself? ${ }^{24}$ I later learned that already in 1957 the same question had troubled publisher Kurt Wolff, who had instigated the MDR project. Wolff sought an answer to the question from the eminent art historian Erwin Panofsky (Kurt Wolff to Erwin Panofsky, 7 Dec 1957. Thanks to Sonu Shamdasani for telling me about this letter and providing a copy). But, as I would soon discover, he need not have worried because Jung was not confused on that point. ${ }^{25}$ The single exception, to be discussed later, is

${ }^{23}$ Although Sant' Apollinare in Classe is not in Ravenna itself, Jung's having visited there is suggested by the fact that postcard pictures from there are still in the Jung collection (acc. to Thomas Fischer to the author, 26 Mar 2019), and by Jung's comment about his and Schmid-Guisan's 'highly enjoyable bicycle tour which took us to Ravenna, where we rode along the sand through the waves of the sea' (Jung 1930:761). Classe was Ravenna's ancient port, long since silted in, but still nearer the seaside than Ravenna itself.

24 There is actually one other monument on the UNESCO World Heritage site list in Ravenna, namely the mausoleum of Theodoric, in which no interior decorative program is retained except for the outline of a cross in the roundel above the porphyry bathtubshaped object which presumably served as Theodoric's sarcophagus.

${ }^{25}$ In order to cover the bases on this score when travelling to Ravenna (see below), I set myself beforehand the task of photographing every scene from every mosaic in every UNESCO site, along with anything else I came upon that might seem even remotely relevant. This I was able to accomplish with the only exception being the relatively 
a confusion in the accounts as to whether the vision took place in the Arian Baptistery (the Protocols) or the Baptistery of the Orthodox (all the other accounts except Knoll).

Jung gave one other detail beyond the mosaics we may look to when trying to answer the where question, namely the reference in the Bennett account to the 'bluish light, though there was no artificial lighting'(1985:80). Jung remarks on this unusual blue light in most of the other accounts as well. ${ }^{26}$ The reference to the mysterious blue light endows the accounts with a certain numinous quality, especially given Jung's claim that there had been 'no artificial lighting.' But for me it raised the more straightforward question as to which mosaic programs in which Ravenna buildings might cause such a phenomenon to occur under certain light conditions? And it was actually in thinking about this blue light, that it became obvious that a trip to Ravenna itself would be necessary if I hoped to answer the question posed by my title.

\section{GALLA PLACIDIA'S SAN GIOVANNI EVANGELISTA}

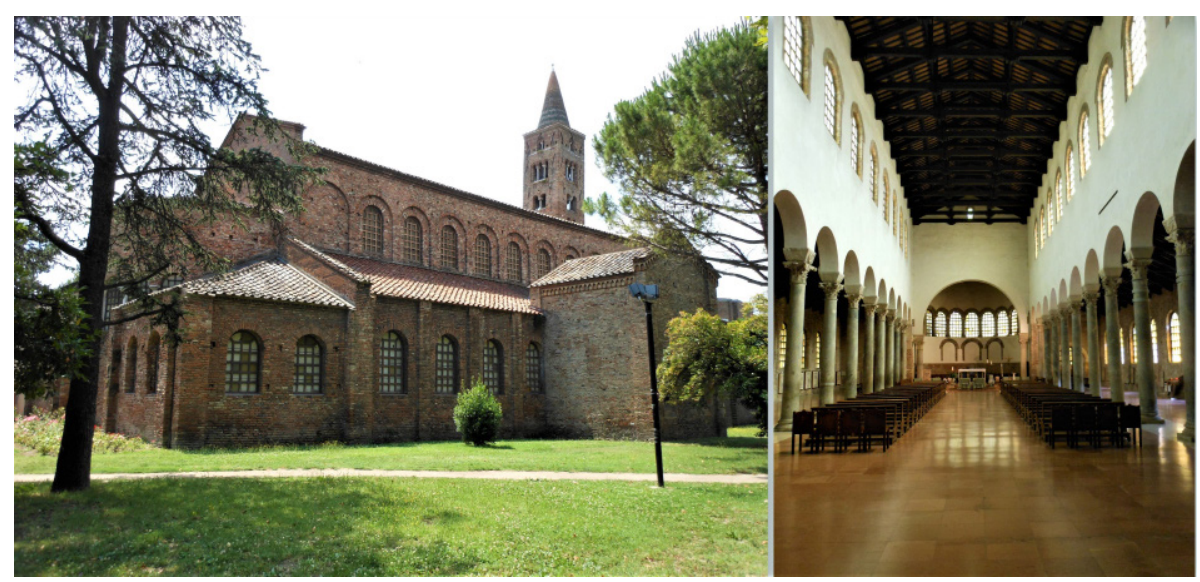

Fig. 2: San Giovanni Evangelista

In view of Jung's account, one of the most surprising things I encountered upon arriving in Ravenna and walking from the train station along Viale Carlo Luigi Farini towards the centre of the old city was the imposing form of the $5^{\text {th }}$ century basilica of San Giovanni Evangelista

small Archiepiscopal Chapel where photography was not permitted.

26 'A misty blue light' (Harding 1948:184), 'the mild blue light that filled the room' (MDR:284), 'ein merkwürdig blaues Licht' (Prot. A.127, cf. B.46, F.621), 'wie mit blauen Licht ausgefüllt' (Knoll). 
grandly rising to my left scarcely more than a block from the station (Fig. 2 ). This was the church Galla Placidia had built and decorated with mosaics in fulfilment of the vow she made at sea while in danger of drowning, the church Jung reported as having been destroyed by fire along with its mosaics in the 'early Middle Ages' (MDR:286). And yet, there it was, still standing. To get into the basilica itself you must go around to the other end of the edifice and enter the atrium courtyard through a $14^{\text {th }}$ century gothic marble gateway that depicts an incident in which John the Evangelist purportedly appeared to the Empress and left his sandal behind in order to provide the basilica with a proper relic (cf. Schoolman 2016:107-108).

As already noted, Jung seemed to imply, or at least that is how several writers have interpreted him, that the visionary mosaics he and Toni Wolff saw in 1932 represented spontaneous recreations of mosaics that had perished long ago in the fire that had allegedly destroyed this basilica. But, in fact, San Giovanni Evangelist wasn't destroyed in their early Middle Ages (although it was badly damaged in World War II by a bomb intended for the nearby rail yard), nor were its mosaics destroyed by fire. They were actually removed in 1568 and replaced with a new iconographic program partly at least consisting of frescos.

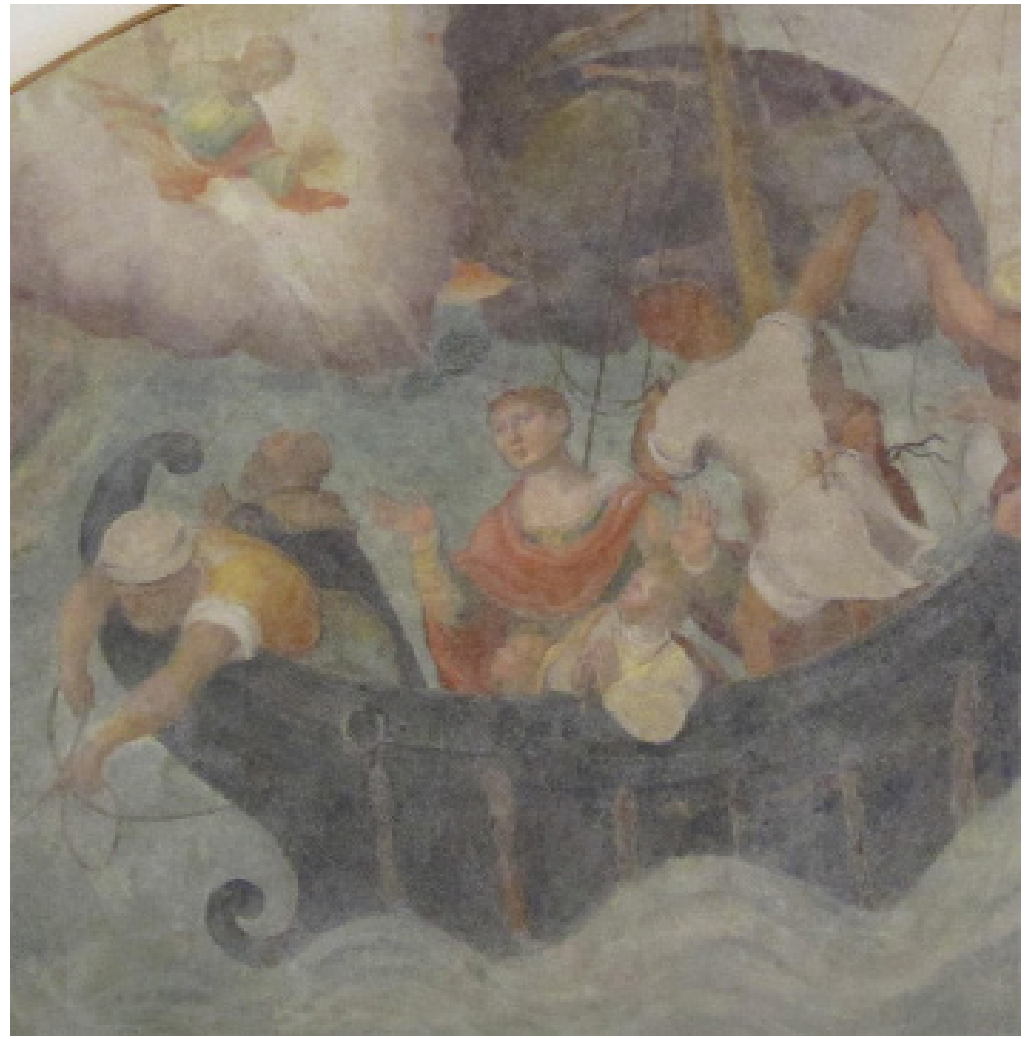

3: Francesco Longhi, Vow of Galla Placidia (detail), 1568 
Jung spoke of the existence of a sketch of Galla Placidia in a boat in the Ambrosiana in Milan, which he says he never saw (MDR:286; Harding 1948:185; Knoll). But there is also still extant a fresco painting by Francesco Longhi nearer at hand that is actually from San Giovanni entitled Vow of Galla Placidia during the Tempest. It is on display in Ravenna itself in the Museo Nazionale Ravenna in the Cloister of San Vitale (Fig. 3). ${ }^{27}$ It was produced in 1568, that is to say, in the same year the old mosaics were taken down, and therefore may have been intended as a replacement for the mosaic version of the scene being removed.

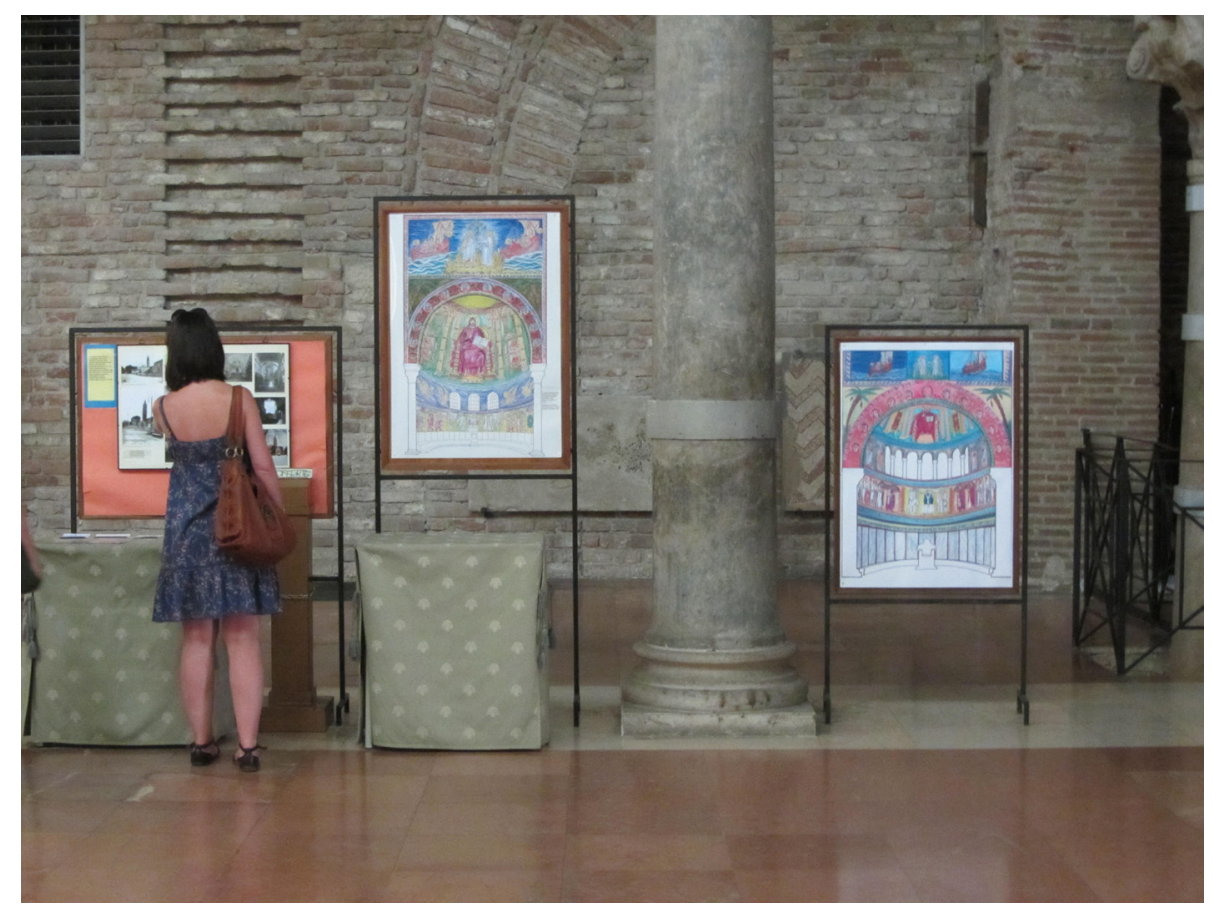

Fig. 4: Reconstructions of the ancient mosaic program in Galla Placidia's San Giovanni Evangelista

One of the first things I encountered upon entering the basilica were two posters representing alternative reconstructions of the original mosaic program (Fig. 4) ${ }^{28}$ Both contain the same basic elements but distributed somewhat differently on the apse wall.

${ }^{27}$ Voto di Galla Placidia durante la tempesta, Francesco Longhi (Ravenna, 1544-1618) 1568, Affresco staccato, Dalla basilica de San Giovanni Evangelista, Ravenna (Museo Nazionale Ravenna, inv. n. 12095).

${ }^{28}$ The relevant description is conveniently available in English in Davis-Weyer (1986:15-17). 
The reason the original mosaics can be confidently recreated is that Girolamo Rossi (Hieronymus Rubeus) provided a full description of them, presumably from personal knowledge, in his Historiarum Ravennatum, libri decem, which was published in 1572, only four years after they were removed (Rossi 1572:85-86). Yet even long before Rossi, the ninth-century writer Agnellus of Ravenna in his Liber pontificalis ecclesiae Ravennatis (Book of the Pontiffs [Bishops] of the Church of Ravenna) had also included descriptions of key details in the mosaic (Agnellus 2004:124,151). ${ }^{29}$

Both reconstructions showed two images of Galla Placidia in a boat on either side of the top-most band. The centrepiece of the entire iconographical program was Christ 'seated on a throne and illuminating the whole basilica' (Rossi in Davis-Weyer 1986:17). He is surrounded by twelve sealed books and holds an open book in his hand that contains the words of Matthew 5:7, 'Blessed are the merciful for the shall obtain mercy.' In the centre above the bishop's cathedra was a mosaic depiction of St. Peter Chrysologus (431-450) with his arms outstretched chanting the mass. We shall have more to say about Chrysologus later.

According to the information we have, then, the mosaics Jung and Toni Wolff saw in the Baptistery of the Orthodox were likely not miraculous recreations of the mosaics that once decorated San Giovanni Evangelista. The descriptions given by Agnellus, Rossi, and Muratori, in any case, do not match those given by Jung. ${ }^{30}$

\section{THE 'SO-CALLED’ TOMB OF GALLA PLACIDIA}

Another point of interest relating to the interpretation of Jung's attribution of the mosaic vision to 'a projection of his anima upon Galla Placidia,' is the question of where Galla Placidia's body was actually buried, where her actual tomb is to be found. Jung felt that the fact that he and Toni

\footnotetext{
${ }^{29}$ The above-mentioned texts by Agnellus and Rossi, along with another, In dedicatione Ecclesiae Sancti Johannis Evangelistae and Item de Dedicatione Ecclesiae Sancti Johannis Evangelistae in Ludovico Muratori's Rerum italicarum Scriptore (1725:567572), are also conveniently displayed in parallel columns in Deichmann (1974:108111), with Deichmann's introduction on 107-108 and his extensive commentary on 111-124.

${ }^{30}$ Granting that some doubt remains due to the fact that the 9th and 16th century accounts only relate to the decoration of the front of the Church, the apse and surrounding wall. One of the side chapels, for example, contains the remnants of frescoes attributed to Giotto (1266-1337) of a crucifixion scene on the wall and of the four Evangelists and Doctors of the Church on the ceiling.
} 
Wolff went directly from the building now called Galla Placidia's tomb to the baptistery was instrumental in bringing about the visionary event. But whatever connection Jung experienced with the Empress Galla Placidia, it did not arise from a nearness of her physical remains. The tomb contains three sarcophagi, one of which is labeled 'Sarcophagus so-called of "Galla Placidia", and goes on to explain that it is really not Galla Placidia's, since she 'was almost certainly buried in Rome, where she died in 450 A.D'. Despite the little yellow signs outside the monument which still describe it as the 'Mausoleo di Galla Placidia,' in scholarly writing since Bovini 'the structure has been more correctly referred to as the "so-called mausoleum", (Bovini 1950:14-18;1956:7, acc. to Deliyannis 2001:289-291, n. 2). There is in fact no contemporary account as to where Galla Placidia was buried (Deliyannis 2001:289), nor of the construction of the cruciform chapel in Ravenna now identified as her tomb (Mackie 1995:396). ${ }^{31}$ The claim that Galla Placidia was buried there dates from the $13^{\text {th }}$ century (Deliyannis 2001:293), although in the $9^{\text {th }}$ century Agnellus passed along a popular belief that she was buried in the monasterium of St. Nazarius, a part of San Vitale where a number of the bishops of Ravenna were buried. San Vitale, however, was not built until the century after Galla Placidia's death (Agnellus 2004:151, n. 33; Deliyannis 2001:293-294).

\section{THE ARIAN BAPTISTERY OR THE BAPTISTERY OF THE ORTHODOX?}

The confusion in the sources alluded to earlier, as to whether the mosaic vision took place in the Arian Baptistery and the Baptistery of the Orthodox, it became immediately clear upon visiting both that the latter was eminently more likely. Both are built on more or less the same pattern, although the Baptistery of the Orthodox is taller. Both are octagonal with almost identical windows. In his description of the setting of the vision Jung told Bennet that 'In the centre was the font, it was big for it was used for immersion' (Bennet 1985:80). That is true of the Baptistery of the Orthodox, which indeed has an enormous baptismal font, but not of the Arian Baptistery, whose font is not present and was already gone before either of Jung's Ravenna trips. ${ }^{32}$

\footnotetext{
${ }^{31}$ Mackie 1995:396: '...there is no mention of the mausoleum [Ravenna's so-called Tomb of Galla Placidia] in any document or inscription until half a millennium after it was built'.

${ }^{32}$ F. Hamilton Jackson's remark that 'In the pavement, which is six or seven feet above the original level, is a large round piece of Oriental granite, which is thought to be part
} 
In addition, the walls of the Arian Baptistery are all of bare, sandy coloured, reused Roman bricks (Deliyannis 2010:180). No ancient decoration of any kind remains on the walls. There is only the famous central ceiling mosaic showing the baptism of Jesus. In contrast, the Baptistery of the Orthodox is heavily decorated throughout, and very much dominated by a deep-blue mosaic ground.

It further became clear that if Jung's memory was correct in equating blue light with the building where the mosaic vision took place, it reduced the possibilities to three locations: (1) the Tomb of Galla Placidia itself, (2) the chapel in the Archiepiscopal Palace/Museum, and (3) The Baptistery of the Orthodox. The intensity of the effect in these three locations is due to the dominant dark-blue ground of the mosaics and differs somewhat according to light and weather conditions outside. ${ }^{33}$ But as to Jung's claim that there was 'no artificial lighting,' at the time, while such might have been a possibility during his 1914 visit, by 1932 electric lights would have almost certainly been in place, probably since c. 1911 for the Tomb of Galla Placidia and c. 1919 for the Archiepiscopal Palace/Museum and the Baptistery of the Orthodox. ${ }^{34}$

Very possibly Jung hadn't noticed the electric lights because they were unobtrusively placed, just as they are today.

In any case my initial visit to all three of these buildings left me feeling much as C.A. Meier must have felt when he visited in 1932 and reported back that the mosaics Jung saw were not there. I suspect the problem was that the expectations provided in advance as to what Meier (and I) were looking for, caused both of us to overlook key details that told the real story. In fact, what I ultimately discovered in Ravenna, was that the things Jung spoke about were/are, in a sense, really there, just where

of the Arian font' (1906:261). Jackson's description agrees precisely with what we see there now. At present the granite circle in question is smooth and flush with the rest of the pavement, with a crack that runs through it.

${ }^{33}$ The site where this blue light is most strongly displayed is in the Tomb of Galla Placidia. The windows of thinly sliced, translucent carmel-coloured alabaster limit and tint the incoming light, making the discreetly placed electric light the primary source of light. The author vividly recalls a tourist in the tomb whose white shirt and white socks appeared almost neon blue.

${ }^{34}$ Paola Novara of the Museo Nazionale Ravenna, informs me that electric lights came to Sant' Apollinare Nuovo in 1903-1905, to the Cathedral in 1919, to San Vitale in 1911, and to the Cloister of San Vitale in 1914. She also suggested that the Mausoleum of Galla Placidia likely received electric lights at around the same time as San Vitale and the Baptistery of the Orthodox at around the same time as the Cathedral (which would probably also apply to the Archiepiscopal Palace and Chapel) (Paola Novara to the author, Feb 2016). 
he said they were, in the Baptistery of the Orthodox. But not in the form he remembered.

I would like to say I discovered the crucial key piece of evidence through my own observation in the baptistery, but in fact when I entered it the second time, I already knew what it was. I had stumbled across it in the little shop next door in the Archiepiscopal Palace, for all I know the same location Jung described as 'a shop opposite,' where he and Toni Wolff had gone looking for photographs more than 80 years before (Bennet 1985:81). It was in a small book by a certain Giovanni Montanari, published by the Diocese of Ravenna (2001:73-74). The remarkable thing is that there was really no reason I should have missed it on my first visit to the baptistry, but I did. And because I did, it makes me less surprised that C.A. Meier did as well.

The accompanying chart marked Figure 5 shows the contents of the four visionary mosaics as presented in Jung's five different accounts of them. We notice that the only scene that all the accounts agree on was Peter sinking beneath the waves, and Christ rescuing him. It was clearly the one Jung thought most significant, due to the danger of death by drowning implied.

\begin{tabular}{|c|c|c|c|c|}
\hline $\begin{array}{c}\text { Oct } 1932 \\
\text { (Jung 1932a:16) }\end{array}$ & $\begin{array}{c}\text { Jun } 1948 \\
\text { (Harding } \\
\text { 1948:184) }\end{array}$ & $\begin{array}{c}\text { Jan } 1957 \\
\text { (Bennet 1985:81) }\end{array}$ & $\begin{array}{c}\text { Aug 1957 } \\
\text { (MDR:284-285/ } \\
\text { Prot. A.127, etc.) }\end{array}$ & $\begin{array}{r}\text { May } 1958 \\
\text { (Max Knoll) }\end{array}$ \\
\hline $\begin{array}{l}\text { (1) Peter sinks } \\
\text { under the waves }\end{array}$ & $\begin{array}{l}\text { (1) Peter sinks } \\
\text { under the waves }\end{array}$ & $\begin{array}{l}\text { (1) Peter sinks } \\
\text { under the waves }\end{array}$ & $\begin{array}{l}\text { (4) Peter sinks } \\
\text { under the waves } \\
\left(\underline{\text { West })^{*}}\right.\end{array}$ & $\begin{array}{l}\text { (4) Peter sinks } \\
\text { under the waves }\end{array}$ \\
\hline (2) Not named & $\begin{array}{l}\text { (2) Moses } \\
\text { bringing water } \\
\text { from the rock } \\
\end{array}$ & $\begin{array}{l}\text { (2) Passing } \\
\text { through the Red } \\
\text { Sea }\end{array}$ & $\begin{array}{l}\text { (2) Passing } \\
\text { through the Red } \\
\text { Sea (North) } \\
\end{array}$ & $\begin{array}{l}\text { (2) Passing } \\
\text { through the Red } \\
\text { Sea }\end{array}$ \\
\hline $\begin{array}{l}\text { (3) Christ's } \\
\text { baptism }\end{array}$ & $\begin{array}{l}\text { (3) Jonah and } \\
\text { the whale }\end{array}$ & $\begin{array}{l}\text { (3) Naaman the } \\
\text { leper }\end{array}$ & $\begin{array}{l}\text { (3) Naaman the } \\
\text { leper (East) }\end{array}$ & (3) Lazarus \\
\hline $\begin{array}{l}\text { (4) Christ's } \\
\text { baptism }\end{array}$ & $\begin{array}{l}\text { (4) Miraculous } \\
\text { catch of fish }\end{array}$ & $\begin{array}{l}\text { (4) Christ's } \\
\text { baptism }\end{array}$ & $\begin{array}{l}\text { (1) Christ's } \\
\text { baptism (South) }\end{array}$ & $\begin{array}{l}\text { (1) Christ's } \\
\text { baptism }\end{array}$ \\
\hline
\end{tabular}

*MDR and the Protocols agree on the order of mention, but the only mosaic explicitly associated with a point of the compass in the Protocols is the one showing Peter sinking, which they link to the West side (underlined) (A.127, c.f. B.46, F.621).

Fig. 5: The 5 Versions of the Mosaic Vision

In his 12 October 1932 lecture on Kundalini Yoga, Jung contrasted present day Christianity, in which 'there is no danger in being baptized' with the baptism portrayed in the Baptistery of the Orthodox which, he said, dates 'from the fourth or the beginning of the fifth century, when the baptism was still a mystery cult,' and 'a symbolical drowning,' 
accompanied by 'the danger of being swallowed by the monster' (Jung 1932a:16). However, Jung's description of the interpretation of baptism as 'still a mystery cult,' at the time of the original decoration of the Baptistery of the Orthodox is not correct.

Christianity at that period in Ravenna rather represented triumphant Imperial Orthodoxy. By the time the baptistery was initially built in the early $5^{\text {th }}$ century under Ravenna's $16^{\text {th }}$ bishop, Ursus (c. 405-431?), and decorated under its $18^{\text {th }}$ bishop, Neon (c. 450-473), the main lines of Christian Orthodoxy had already been firmly drawn. So there can be little doubt as to what the actual baptismal liturgy was like that was performed in the baptistery in its earliest days, nor how little it would have differed from the current baptismal liturgies of the Western Roman Catholic and the Eastern Orthodox Churches. ${ }^{35}$

This can be clearly seen in descriptions of the baptismal liturgy in the contemporary writings of Ravenna's prolific Peter Chrysologus, Ravenna's $17^{\text {th }}$ bishop (between Ursus and Neon), and especially in those given by the nearby and near-contemporary Ambrose of Milan (374-397). In fact, the baptismal ritual as it would have been practiced in the early days of the Baptistery of the Orthodox has been ably reconstructed by Wharton (1987:358-375), and further described by Marchal (2016:22-25, 27-28). ${ }^{36}$

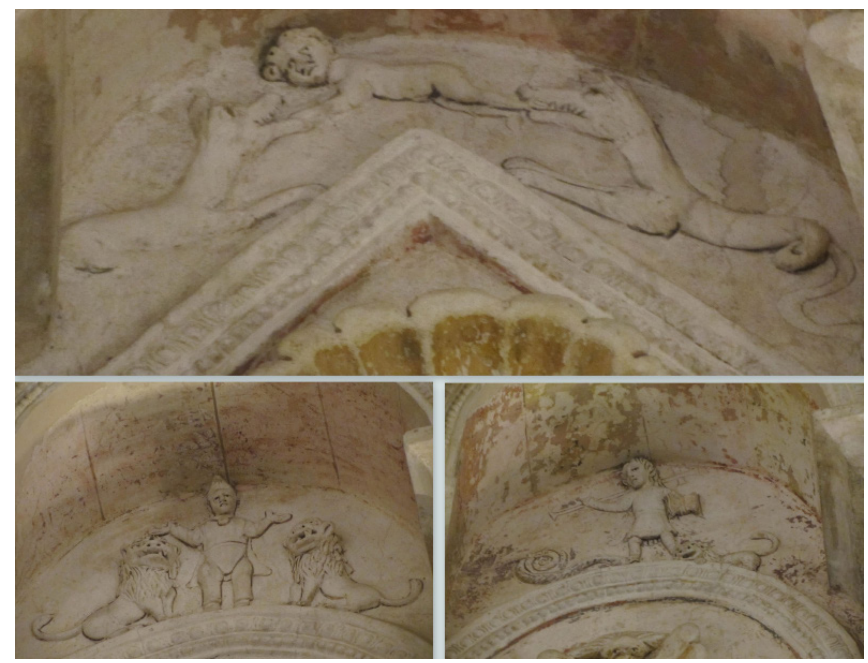

Fig. 6: Stucco figures of Jonah and the Sea Monsters, Daniel in the Lion's Den, and Christus Victor

\footnotetext{
${ }^{35}$ With the exception of adult baptism taking place in the nude at that time, or at least in an advanced state of undress (Ferguson 2009:330), and the rise to universal prominence of infant baptism after this period.

${ }^{36}$ The decisive $4^{\text {th }}$ ecumenical council, the Council of Chalcedon, took place during Ravenna's Bishop Neon's second year in office (451). We will recall that it was Neon who decorated the Baptistery of the Orthodox.
} 
Despite all this, Jung was correct in saying that the association of baptism to drowning, and the danger of death generally, is present to some degree in the baptistery's decorative program. In the second band of decorations, distributed between the baptistery's eight windows, are stucco figures of sixteen Old Testament prophets. In small niches above each prophet are much smaller stucco scenes, three of which are especially relevant in linking baptism to the danger of death. In one account Jung spoke a mosaic depicting Jonah and the whale. Although there is no such mosaic in the baptistery, one of the small stuccos in this second band shows Jonah being attacked by not one but two whales (or more precisely sea monsters). There is also another small stucco showing Daniel between two lions in the lions' den. And then, as if associating elements from those two, a third shows a Christus Victor scene, a youthful Christ as victorious warrior, with his cross over his shoulder, an open bible in his hand, and his feet on the necks of a serpent and a lion (Fig. 6). ${ }^{37}$

To us the animals that have taken hold of Jonah look more like dogs than sea monsters, but such they are. Indeed, similar features (e.g., ears, front legs) also appear on the sea monster waiting to swallow Jonah on the $6^{\text {th }}$ century ivory Murano Diptych in the Museo Nazionale Ravenna, although in that case the animal has a proper sea-monster tail (Fig. 7).

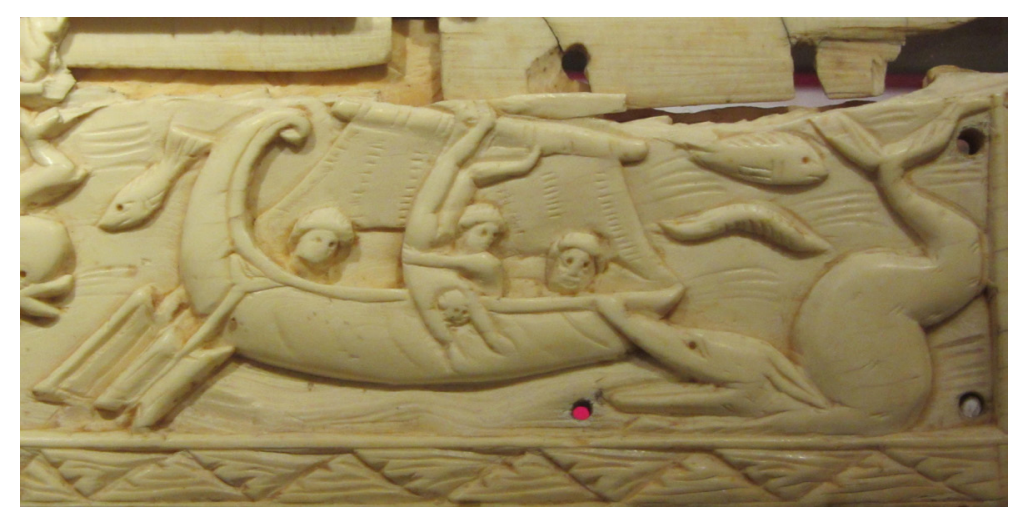

Fig. 7: Jonah scene from the Dittico di Murano (Murano Diptych), First half of the $6^{\text {th }}$ century, Museo Nazionale Ravenna (Inv. N. 1002).

That Jung remembered seeing a depiction of Jonah is explicitly mentioned in the Esther Harding account (1948:184), but there is a reference in Jung's 1932 account that may also allude to the Jonah stucco

${ }^{37}$ This third image echoes the more famous mosaic of the same motif above the entry of the Archiepiscopal Chapel. 
when he speaks about the decorations of the chapel associating baptism 'with the danger of being swallowed by the monster' (Jung 1932a:160).

In early Christian art, the stories of Jonah and Daniel were commonly seen as symbolically representative of death and resurrection. And yet Jung intuited correctly that finding such scenes in a baptistery was at the very least unusual. As Robin M. Jensen points out: 'Despite their symbolic associations with baptismal rebirth and their frequent appearance in funereal iconography [...] Lazarus, Jonah, and Daniel rarely, if ever, appear in surviving decoration of early Christian baptisteries.' 'The exception,' she explains in a footnote, 'is the Orthodox Baptistery in Ravenna, which includes stucco decoration that shows Jonah and Daniel' (Jensen 2012:149, n. 49).

But all this is secondary to what Meier had missed and I hadn't noticed on my own first visit. In the initial 1932 account, Jung only mentions two baptism scenes and the scene of Peter sinking and calling out to Jesus. The later, more elaborate descriptions of four large mosaics all date from many years later, one from 1948, two from 1957, and one from 1958. And, as we said before, the only mosaic that appears in all his accounts is that of Peter sinking and calling out to Jesus. As it turns out, Jung wasn't making that up, he was simply misremembering it. What one has to do when visiting the chapel to see this is to read the elaborate Latin mosaic passages that run along the top edges of the arches above the baptistery's four large niches. In particular it is the inscription on the south-west arch, just to your right as you enter the octagonal building, that captured Jung's particular attention. That inscription paraphrases Matthew 14:29-32 and reads: 'Jesus, walking on the sea, takes the sinking Peter by the hand and at the command of the Lord the wind ceased.' This was the 'crucial key' I spoke of earlier. ${ }^{38}$ The four arches contain two paraphrases of New Testament verses, and two quotations from the Latin Vulgate Book of Psalms as follows:

\footnotetext{
${ }^{38}$ Montanari 2001:73-74. I subsequently found it discussed in a number of works, including especially Kostof (1965:59), whose general discussion of the arches (5793) contributed significantly to my discussion here. For large clear photographs of the Ravenna mosaics, including the interior decorations of the Baptistery of the Orthodox, see Dresken-Weiland (2016).
} 


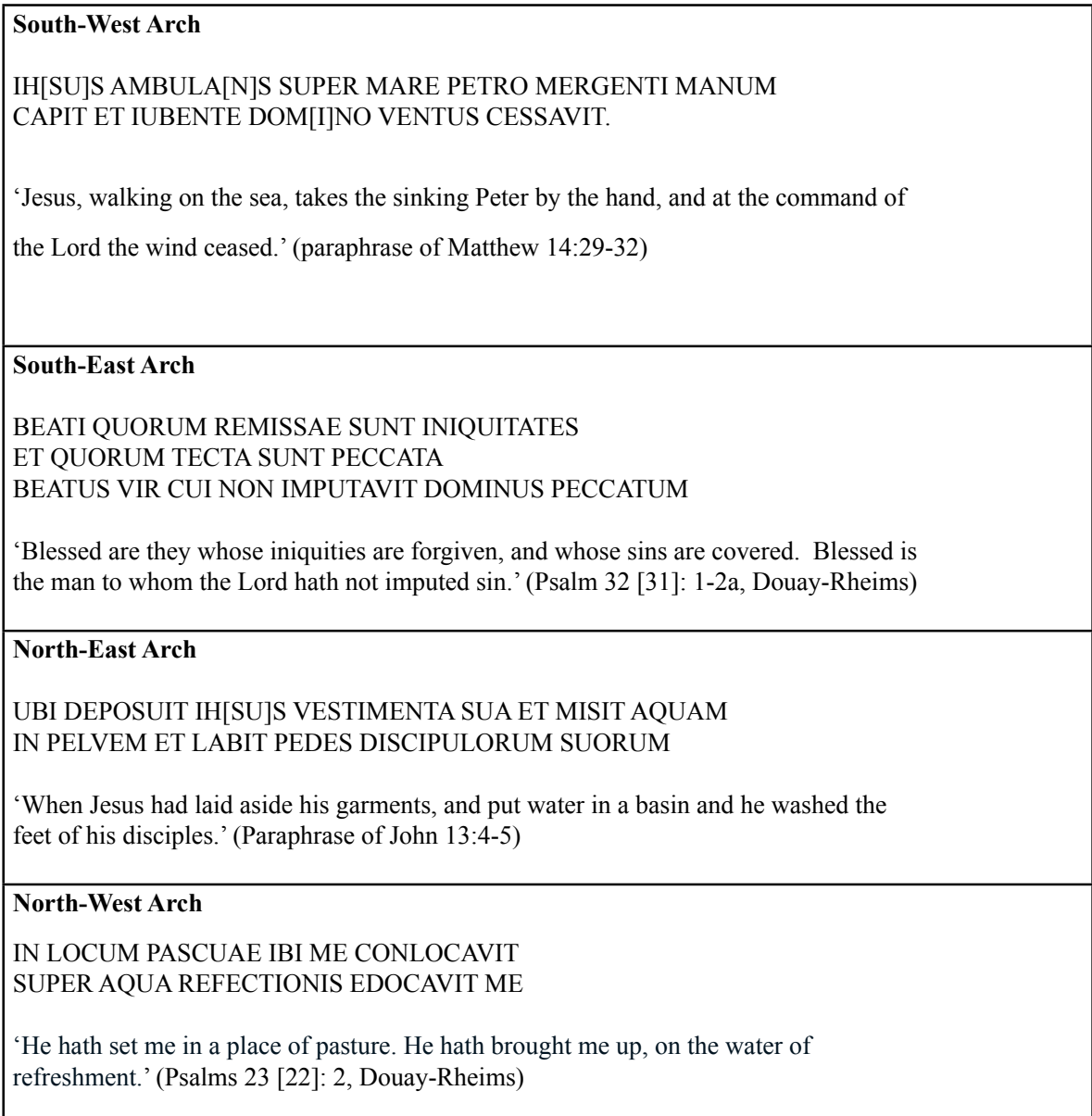

All four inscriptions have to do, directly or indirectly, with water, but not with the danger of drowning. The only one reflecting that is the one with Peter sinking down and calling for help, the only mosaic Jung mentioned in all the accounts (Fig. 8). There are a number of things that need to be said about this arch.

When we ask how far back the mosaic inscription about Peter's drowning goes, that is to say, whether it goes all the way back to the time of the original decoration, when according to Jung, Christianity was 'still a mystery cult,' there is a complication.

When Giovanni Ciampini made the earliest extant depiction of the baptistery's arches and their inscriptions in the late seventeenth century, he represented the arch that today contains the inscription about Peter as completely blank except for a portion of a central monogram (Ciampini 
1690-1699:234-235, P1. 69.2; see also Bard 1844:27). ${ }^{39}$ (See Fig. 9).

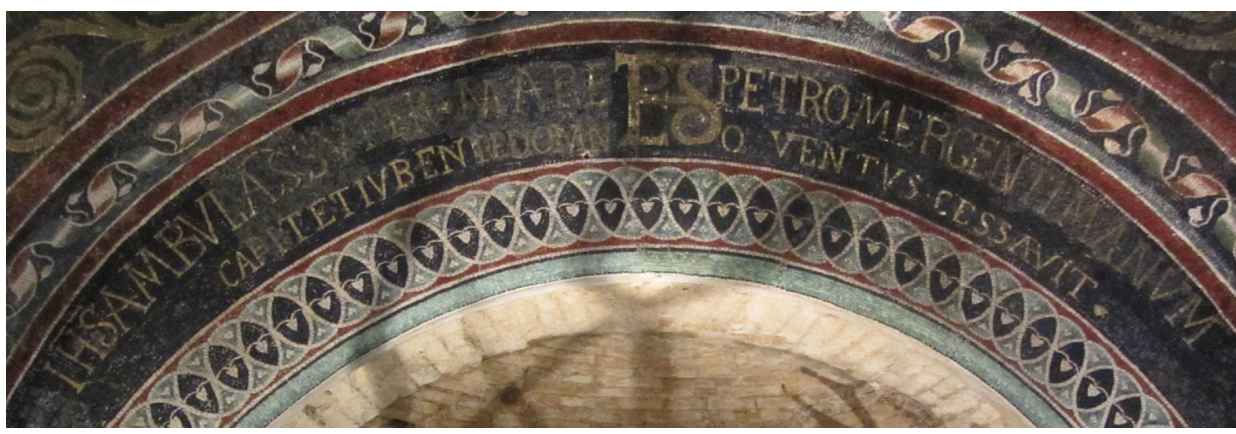

Fig. 8: The south-west arch in the Baptistery of the Orthodox, which reads: $I h$ [su]s ambula [n]s super mare Petro mergenti manum capit et iubente Dom [i]no ventus cessavit ('Jesus, walking on the sea, takes the sinking Peter by the hand and at the command of the Lord the wind ceased').

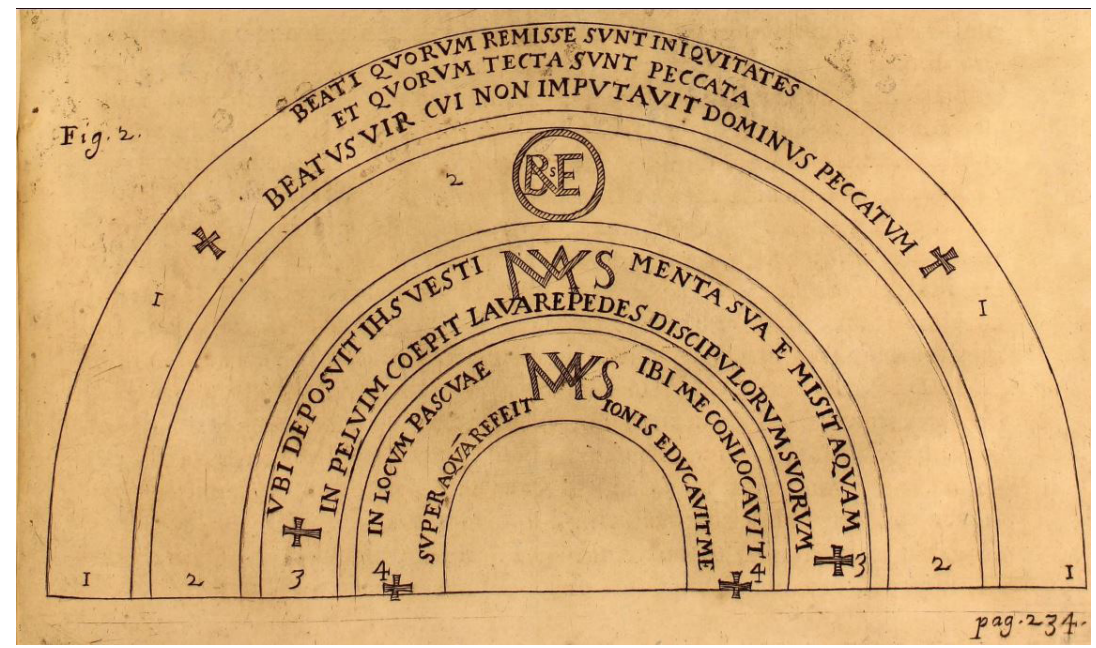

Fig. 9: Ciampini's 17th cent. Baptistery of the Orthodox arches showing the South-Western 'drowning Peter' arch as completely blank except for a monogram.

And yet later, when Rafaelle Garrucci proposed his own restoration of the inscriptions he apparently felt that at least some of the words of the Peter inscription could still be discerned. Presenting the inscription as it is today, we put those letters Garrucci thought were still present in uppercase

\footnotetext{
${ }^{39}$ But notice that the central monogram in Ciampini's drawing does not match the current one. He also appears to have simply recopied the monogram of the third band down into the fourth, perhaps because the actual monogram in the fourth band was much more complicated.
} 
and those completely lost in lowercase: 'ih[su]s AMBULAns SUPER MARE PETRO MERGENTI MANum capit et iubenTE DOM[I]No ventus cessavit' (Garrucci 1873-1881:37-38). If what Garrucci says is correct, the major elements of the statement survived and the basic inscription might indeed be ancient. Garrucci's proposed restoration differed slightly from the one we see today, and the one Jung would have seen in 1932. The current restoration was already in place by 1878 (Richter 1878:22).

Meier, who was apparently quite fluent in Latin (Kirsh 1996:292), failed to notice these mosaic arch inscriptions. Yet it is not entirely surprising given the fact that abbreviations are used, words run together, and the passages of Scripture are interrupted in the middle of three of the four arches by complicated monograms. But, as we said before, it also may simply be because he had been given to expect pictures not texts. But however that may be, Jung himself appears to have noticed them and worked out at least the one dealing with Peter sinking down.

\section{PETER SINKING OR THE JORDAN RISING?}

The other item calling for explanation is Jung's firm insistence that he remembered not just a text but an image of Peter's sinking and being rescued. In all his accounts he mentions this, but stresses it most emphatically in the $M D R$ :

I retained the most distinct memory of the mosaic of Peter sinking, and to this day can see every detail before my eyes: the blue of the sea, individual chips of the mosaic, the inscribed scrolls proceeding from the mouths of Peter and Christ, which I attempted to decipher (MDR:285, agreeing with the Prot. A.128, cf. B.47, F.622).

It is important to remember that Jung's recollection here was taken down in 1957, a full quarter century after the event. Furthermore, two details in Jung's account might seem to signal the fact that his memory of what he saw was not precise. One is his reference to the 'inscribed scrolls [Spruchbänder], proceeding from the mouths of Peter and Christ' (Prot. A.128, cf. B.47, F.622 and ETG:313). In saying this Jung is anachronistically projecting a feature very common, say, in $14^{\text {th }}$ or $15^{\text {th }}$ century European art back into the $4^{\text {th }}$ through $6^{\text {th }}$ century Christian mosaics of Ravenna where such are not to be found. The other detail is that despite the mention here of 'individual chips of 
the mosaic,' a shadow of doubt as to whether the four scenes Jung saw were mosaics or frescos is reflected in the Protocols, the remainders of which show themselves in the use of the compromise term 'mosaic frescoes' to describe them in MDR (284 = Mosaikfresken in ETG:312). The Protocols themselves alternate between calling them mosaics and frescoes. ${ }^{40}$ However, It is actually hard to believe that this confusion derived from Jung himself, given the extent to which he attempted to simulate mosaics in his own art, as for example, in the Red Book (Hoch 2018:41-42 and Jung 2009:11,32,72, 79, 107,133).

Since we now know that Jung was responding in other cases to real items in the baptistery, it seems likely as well that he did not simply invent or imagine the image he had in mind of Peter sinking down. That being the case, an explanation might be found in Jung's having actually misinterpreted another item in the baptistery's iconographic program that was actually there, but did not represent Peter at all.

In the baptismal scene medallion on the ceiling of the baptistery, we are not surprised to see the two figures of John the Baptist and Jesus. And yet, on the lower right of the mosaic we also see a third figure emerging from the water, a figure whom, I am suggesting, Jung took to be Peter sinking beneath the waves and lifting his hand towards Jesus (Fig. 10).

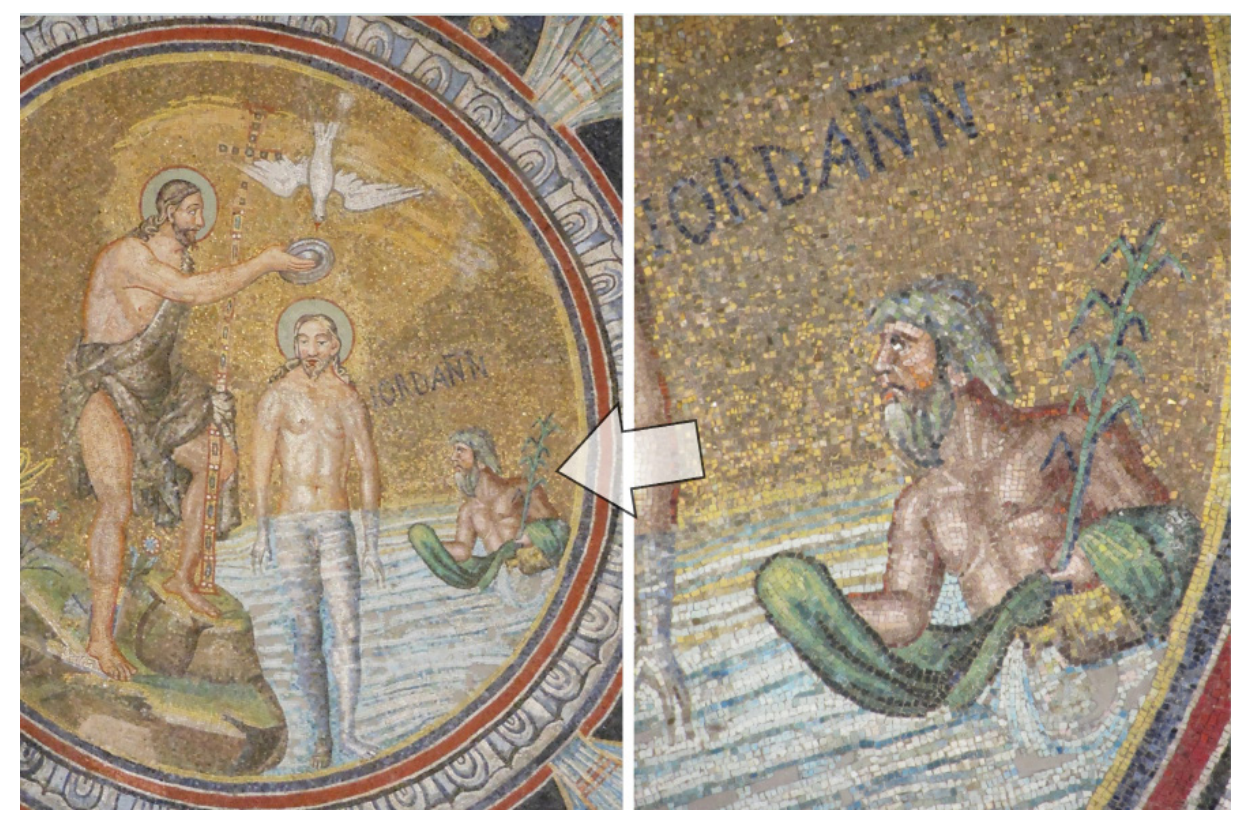

Fig. 10: The Personified Jordan does homage to Jesus, The Baptistery of the Orthodox

${ }^{40}$ Especially Prot. A.128 where the original 'Fresken' is marked out with 'Mosaiken' typed in above it. The correction is then taken over in the two later drafts, B.47, F. 622. See, also, the use of the two terms in Prot. A.127, B.46, F.621. 
But the figure is not Peter, he is the river god representing a personification of the Jordan river (Jensen 1993:36). As strange as it may seem to us now, the presence of the personified Jordan in scenes of the Baptism of Jesus was already on its way to becoming an iconographical commonplace when the mosaic was first installed. The reason he is there is to show the reaction of the Jordan to the baptism of Jesus. We see him as well in the baptismal scene of Ravenna's Arian Baptistery (Fig. 11), and in the baptism panel on the back of the sixth-century throne of Bishop Maximian on display in Ravenna's Archiepiscopal Palace/Museum, just next door to the Baptistery of the Orthodox. Another example from the period is a sixth-century ivory in the British Museum.

The theme of the personified Jordan reacting to Jesus' baptism was also a common motif in the preaching of the period. We see this, for example, in a Sermon by St. Peter Chrysologus (d. 450):

...if the Father thunders from heaven, if the Son stirs up the waters of the Jordan, if the Holy Spirit appears in bodily fashion from on high, why is it that the Jordan, who fled at the presence of the Ark of the Covenant, did not run away when the whole Trinity is present? Why is it? It is because the one who shows homage and deference [i.e., the Jordan] begins to be fearful no longer. (Sermon 169.5, A Fourth on Epiphany / Chrysologus 2005:280).

Chrysologus, one of the figures depicted in the mosaics of Galla Placidia's San Giovanni Evangelista, was the bishop of Ravenna and the immediate predecessor of bishop Neon who originally decorated the Baptistery of the Orthodox..$^{41}$

Other examples may be cited. St. Jerome (d. 420) similarly personifies the Jordan, which, he says, 'dried up when Josue led the Israelites into the Land of Promise, [but] now longed to gather together all its waters into one place, if it could, to bathe the body of the Lord' (Homily 89, For Epiphany / Jerome 2004:230). Or again, slightly earlier, St. Cyril of Jerusalem (d. 386) who wrote that: 'Since then before His coming in the flesh, the sea saw Him and fled, and Jordan was driven back, the Lord took to Himself His body, that the sea might endure to behold Him, and that Jordan might without fear receive Him' (Catechetical Lectures 12.15 / Cyril 1839:130).

The depictions of the personified Jordan in the baptismal scenes in

${ }^{41}$ The Baptistery of the Orthodox is sometimes called the Neonian Baptistery because it was originally decorated under Bishop Neon. 
Ravenna's two baptisteries represent him as fearlessly showing deference to Christ, as in Chrysologus's and Cyril's comments. But in the one on the back of Maximian's ivory throne and the British Museum ivory he is either busily gathering up water, as in Jerome's remarks, or turning to flee, in reenactment and fulfillment of the Exodus event described in Psalms 114:3: 'The sea looked and fled, Jordan turned back' (NRSV).

The inclusion of the personified Jordan has persisted in Orthodox Iconography, such that, as Jensen points out, 'The figure still appears in most Orthodox Icons of the Baptism' (Jensen 2012:186, n. 34, cf. Ouspensky \& Lossky 1982:164-165). It is he that is alluded to, though not explicitly named, in the Painters Manual of the $17^{\text {th }}$ and $18^{\text {th }}$ century Orthodox writer Dionysius of Fourna, who indicates in his pattern for Icons of the Baptism of Jesus, that 'Below the Forerunner in the Jordan is a naked old man lying bent up, who looks back at Christ in fear and holds an urn from which pours water' (1989:33). Although none of the Ravenna depictions show the personified Jordan with an urn with water pouring out of it, an ivory panel from the Werden Casket ( $5^{\text {th }}$ cent.-800), now in London's Victoria and Albert Museum, does. ${ }^{42}$ Similarly the famous Drago Sacramentary (c. 845-55) $)^{43}$ combines the Jordan's urn with Jerome's theme of the river's longing 'to gather together all its waters into one place [...] to bathe the body of the Lord.' 44

If we are right in thinking that Jung made the mistake described, it helps us make sense of his comment that 'at least the main features' of what he and Toni Wolff saw 'had been the same.' (MDR:285). According to Bennet, when Jung told Wolff the news that no such mosaics existed, she responded, 'That's ridiculous, $I$ saw them with my own eyes and you

42 Jensen dates it to the early $5^{\text {th }}$ century (2012:186, Fig. 5.1), but the Victoria and Albert Museum settles instead on a date of 'about 800' (http://collections.vam.ac.uk/ item/O92731/the-annunciation-at-the-spring-panel-unknown/).

${ }^{43}$ Paris, Bibliothèque Nationale (MS lat. 9428).

44 The theme of the piling up of the Jordan's waters continued to be encountered in baptismal scenes even where the Jordan was not personified. One of the most remarkable examples is the dramatic upward thrusting water that dominates the composition of a $9^{\text {th }}$ cent. ivory cover on a Gospel book now in the Bayerische Staatsbibliothek (BSB Clm 4451). In the ivory baptism scene on the Svanhild portable altar in the museum of Austria's Stift Melk (c. 1050-1075?), Jesus is shown wrapped to his chest in water as one might be wrapped in a blanket. We sometimes as well see scenes of Jesus being baptized simply in a free-standing pile of water, see e.g., Rainer (Renier) of Huy's Baptismal Font at St. Bartholomew's Church, Liège, Belgium (11071118), the South Netherlandish plaque (1150-1175) at the Metropolitan Museum in New York (17.190.430), and the $13^{\text {th }}$ cent. French enameled and gilded copper Baptism of Christ plaque at the Boston Museum of Fine Art (50.858). 

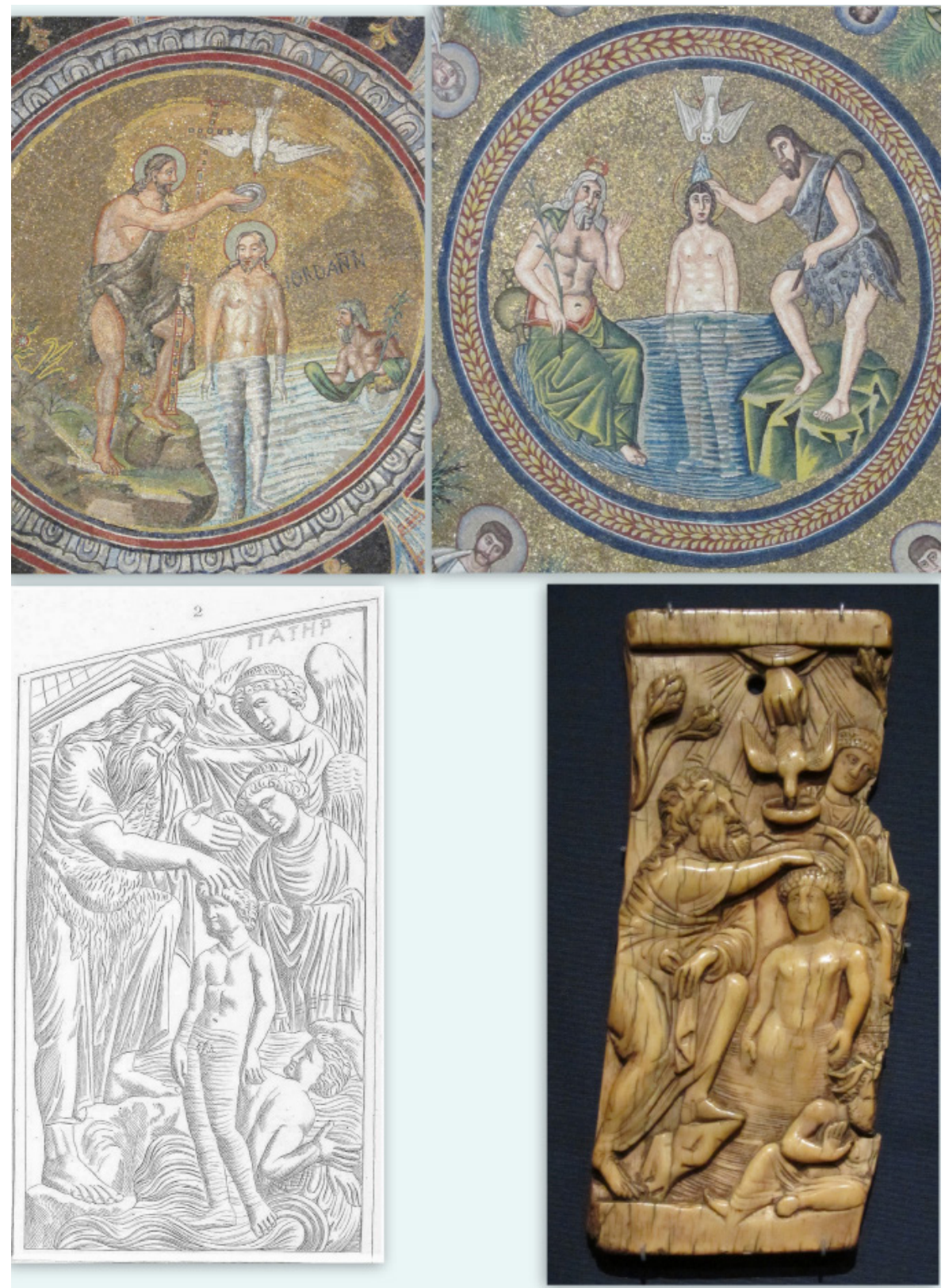

Fig. 11: Scenes with Jordan Personified. (R-L) Top: the Baptistery of the Orthodox, The Arian Baptistery. Bottom: Maximian's ivory throne (Garrucci), A $6^{\text {th }}$ cent. ivory in the British Museum. 
talked of them for about twenty minutes!' (Bennet 1985:81, my italics). To put it in another way, Toni Wolff saw things in the baptistery and Jung interpreted what she saw for her. And from this perspective Wolff could indeed have felt very confident that she really had 'seen' what Jung was describing.

Another point it makes sense of is Jung's firm conviction about seeing 'the blue of the sea, individual chips of the mosaic, the inscribed scrolls proceeding from the mouths of Peter and Christ, which I attempted to decipher' (MDR:285). The mosaic background surrounding the personified Jordan in the baptistery is not blue but gold. However, the stone fragments making up the mosaic settings for the four passages on the arches that Jung 'attempted to decipher' are a deep, beautiful blue.

The picture, then, that finally emerges probably went something like this: Jung and Toni Wolff go to see the Baptistery of the Orthodox. Jung begins translating and explaining what is written above the arches. When he comes to the one about Peter sinking, he starts to make connections to other links between baptism and death in the larger iconographical program of the baptistery. He points out the mosaic in the centre of the ceiling that seemed to him to represent a combined scene of the baptism of Jesus by John and the saving of Peter from sinking down in the water. ${ }^{45}$ He calls her attention as well to the three stuccos of Daniel, Jonah, and the triumphant Christ. Afterward he recalls all these details as being presented in four mosaics. But the ultimate organising basis for his memory was provided by the four arches with their Latin inscriptions. ${ }^{46}$

${ }^{45}$ One wonders whether the figure of the personified Jordan might also stand behind Jung's recollection in the two 1957 accounts of a mosaic showing Naaman the Leper being cleansed in the Jordan in the time of the Prophet Elisha (2 Kings 5).

${ }^{46}$ One question that occurred to me in the process of thinking through the issues addressed in this article is the extent to which Jung's (and Toni Wolff's) usually being identified as thinking-intuitive types might have played into Jung's interpretation of the event (Jung \& Freeman 1959:435-436; Wagner \& Wagner 1991, Minute 3:22-34; Champernowne 1980:8). As Jolande Jacobi explains, the intuitive type pays 'little attention to the details but will have no difficulty in discerning the inner meaning of the event, its possible implications and effects [...] in viewing a lovely spring landscape the sensation type will note every detail; the flowers, the trees, the colour of the sky, etc., while the intuitive type will simply register the general atmosphere and colour' (Jacobi 1973:12). And this is precisely what comes through in Jung's descriptions of the mosaic event, a focus on the mood of the scene, the mysterious blue light, the strong sense of identification with Galla Placidia's fearful journey at sea, her oath, and her fear of drowning. A keenly felt sense of atmosphere, which limits the focus of memory to only those details that, as it were, support the overarching mood (cf. Jung 1925:90-92). Although it is admittedly a peripheral question, my own view is that it probably did play a part, and that as such it might be helpful to keep it in mind when analysing other 


\section{CONCLUSION}

On at least five different occasions, C.G. Jung told the story of how he and Toni Wolff saw and discussed four mosaics in Ravenna that did not exist, that had apparently represented some sort of shared visionary experience. It was, he said, 'among the most curious events in my life' (MDR: 285). So far as we know Jung never returned to Ravenna afterwards to investigate the matter further, and his own accounts of it contain significant differences in detail not only with regard to what was seen, i.e., the actual contents of the mosaics, but also precisely when and where the incident took place. Secondary literature discussing the incident has only magnified the confusion surrounding it. The purpose of this article, then, has been to investigate and assess every aspect of this remarkable incident. In the process, the author traveled to Ravenna in order to clarify, to whatever extent possible, what Jung himself might have discovered had he ever returned. The article's principal conclusions are as follows:

First, the Ravenna mosaic incident occurred in 1932, not in 1914 as is currently either asserted or implied in several recent Jung biographies, nor in 1933 or 1934 as is implied in the current English and German editions of Memories, Dreams, Reflections (MDR:284/ETG:312). The 1914 date is based on the evidentially unsubstantial but widely accepted claim that Toni Wolff was Jung's companion on his first trip to Ravenna. So far as we know Jung only visited Ravenna twice, once in 1914, with his friend Hans Schmid-Guisan, and once in 1932, with Toni Wolff. In addition to the bare fact of Wolff's presence with Jung in Ravenna in 1932 rather than 1914, a number of the other elements in Jung's telling of the story conspire to establish beyond doubt that 1932 was the correct date of the Ravenna incident. The implied dates of 1933 and 1934 are the result of imprecise language being used. Jung was not imprecise, however, in the 3 August 1957 interview with Aniela Jaffé that served as the basis for this section of Memories, the date he gave there was 1932.

Second, the incident occurred in Ravenna's Baptistery of the Orthodox, not in the city's equally famous Arian Baptistery as Jung mistakenly recalled on one occasion, nor in any of Ravenna's other mosaic-bearing UNESCO World Heritage buildings.

Third, what Jung and Toni Wolff saw in the Baptistery of the Orthodox did exist. The event was not some sort of didactic parable, nor was it a joint 'fantasy,' as Jung Collected Works editor William McGuire

places in Jung where reports of his experiences play a key role in his analysis of events. 
once called it (William McGuire to J. Fletcher, 18 May 1973. WMcGP Bx 3, Fd 3, MD,LOC), nor, finally, was it a startling example of exteriorization phenomena, according to which, 'constellated unconscious contents often have a tendency to manifest themselves outwardly somehow or other' (Jung 1950:322). What Jung and Wolff saw was actually there but was partly misremembered and partly misinterpreted, and in each case in ways that might seem to fit well with Jung's own self-identification as a thinking-intuitive type (Jung \& Freeman 1959:435-436. See, further, footnote 46). What Jung actually saw were four Latin inscriptions done in mosaic on the baptistery's four inner arches, which, along with three stucco scenes (Daniel in the lion's den, Jonah and the sea monsters, and Christ as Christus Victor), and a misidentified figure in the ceiling mosaic, seemed to contribute to an overarching motif connecting baptism with the danger of death, especially death by drowning. All these elements combined in Jung's memory to become four large mosaics. The only one of these mosaics whose description remained consistent in all Jung's accounts was said to depict Peter crying out while sinking down after trying to walk on the water like Jesus, and Jesus rescuing him. What Jung was misremembering here was the very real Latin inscription on the baptistery's south-west arch that paraphrases Matthew 14:29-32 and reads in English: 'Jesus, walking on the sea, takes the sinking Peter by the hand and at the command of the Lord the wind ceased.' In Memories, Jung speaks of having a 'distinct memory of the mosaic of Peter sinking' with 'every detail before my eyes' (MDR:285). We argue that in this case Jung's recollection was based on a misinterpretation of the scene on the baptistery's ceiling that shows a third figure besides Jesus and John the Baptist rising up out of the water on the right side of the picture with his hand lifted up towards Jesus. The figure actually represents not a sinking Peter, as Jung seems to have thought, but the common iconographical motif of the personified Jordan rising up to do homage to Jesus at his baptism. ${ }^{47}$

47 Special thanks to Thomas Fischer (Director of the Foundation of the Works of C.G. Jung) and Sonu Shamdasani (of the University College London and the Philemon Foundation) for reading and making valuable suggestions on the draft version of this article and for their generous help along the way with crucial information and documentation. Thanks as well to my good friend and former assistant editor at Midwestern Journal of Theology, Josh Lee Mann, who, along with his wife Melanie, read an earlier version of a portion of this article and made helpful suggestions, and to my daughter and son-in-law Sarah and Andreas Löcker, who always stand ready to help me sort out the German. 


\section{REFERENCES}

rvhuggins@hotmail.com

Agnellus of Ravenna. 2004. The Book of the Pontiffs of the Church of Ravenna.Tr. Deborah Mauskopf Deliyannis. Washington, DC: Catholic University Press of America.

Anthony, Maggy. 1990. The Valkeries: The Women Around Jung. Longmead, Shaftesbury, Dorset: Element Books.

Bair, Deirdre. 2003. Jung: A Biography. New York \& Boston: Black Bay Books/Little, Brown.

Bard, Giuseppe. 1844. Dei Monumenti d'architettura bizantina in Ravenna. Ravenna: Ven. Seminario.

Bennet, E.A. 1985. Meetings with Jung: Conversations Recorded During the Years 1946-1961. Zürich: Daimon.

Bovini, Giuseppe. 1950. Il cosiddetto mausoleo di Galla Placidia in Ravenna. Vatican City: Società Amici [delle] Catacombe presso Pontificio Istituto di Archeologia Cristiana.

1956. Ravenna Mosaics. Greenwich, CT: New York Graphic Society.

Champernowne, Irene. 1980. A Memoir of Toni Wolff. Fwd. Joseph. L.Henderson; San Francisco: C.G. Jung Institute of San Francisco.

Chrysologus, Peter. 2005. St. Peter Chrysologus: Selected Sermons, Volume 3. Tr. William B. Palardy. Washington, D.C.: Catholic University of America Press.

Ciampini, Johannis. 1690-1699. Vetera Monimenta. 2 vols. Rome: Joannis Jacobi Komarek.

Clark-Stern, Elizabeth. 2010. Out of the Shadows: A Story of Toni Wolff and Emma Jung. Hamilton: Genoa House.

Cyril of Jerusalem. 1839. The Catechetical Lectures of S. Cyril, Archbishop of Jerusalem. Oxford: John Henry Parker.

Davis-Weyer, Caecilia. 1986 [1971]. Early Medieval Art 300-1100: Sources and Documents.The Medieval Academy Reprints for Teaching 17. Toronto: University of Toronto Press.

Deichmann, Friedrich Wilhelm. 1974. Ravenna: Haupstadt des spätantiken Abenlandes II. Kommentar I. Wiesbaden: Franz Steiner.

Deliyannis, Deborah M. 2001. “"Bury Me in Ravenna?” Appropriating 
Galla Placidia's Body in the Middle Ages,' Studi Medievali 3rd ser. 42 (1): 289-299.

2010. Ravenna in Late Antiquity. Cambridge: Cambridge University Press.

Dionysius of Fourna 1996. The 'Painter's Manual' of Dionysius of Fourna. Tr. Paul Hetherington. Torrance, CA: Oakwood Publications, 1996.

Dresken-Weiland, Jutta. 2016. Mosaics of Ravena: Images and Meaning. Tr. Franziska Dörr and Team Syllabos. Regensburg: Schnell \& Steiner.

Ferguson, Everett. 2009. Baptism in the Early Church: History, Theology, and Liturgy in the First Five Centuries. Grand Rapids, MI / Cambridge: Eerdmans.

Freud, Sigmund. \& Carl G. Jung. 1974. Freud-Jung Letters. Ed. W. McGuire. Tr. R. Manheim \& R. F. C. Hull. Princeton: Princeton University Press.

Garrucci, Raffaele. 1873-1881. Storia della arte cristiana nei primi otto secoli della chiesa. 6 vols. Prato: Francesco Giachetti and Gaetano Gausti.

Hannah, Barbara. 1991. Jung: His Life and Work: A Biographical Memoir. Boston: Shambala.

Jackson, Frederick H. 1906. The Shores of the Adriatic, The Italian Side: An Architectural and Archaeological Pilgrimage. London: John Murray.

Jacobi, Jolande. 1973. The Psychology of C.G. Jung. Intro. C.G. Jung; Tr. Ralph Manheim. New Haven \& London: Yale University Press.

Jansen, Diana Baynes. 2003. Jung's Apprentice: A Biography of Helton Godwin Baynes. Einsiedeln: Daimon.

Harding, Esther. 1948. 'From Esther Hardings Notebooks (1948).' In W. McGuire and R. F. C. Hull (eds.). C.G. Jung Speaking: Interviews and Encounters. Princeton: Princeton University Press, 1987.

Healy, Nan Savage. 2017. Toni Wolff \& C.G. Jung: Collaboration. Los Angeles, CA: Tiberius Press.

Hoch, Medea. 2018. 'C.G. Jung's Concept of Color in the Context of Modern Art'. In Ulrich Hoerni, Thomas Fischer, and Bettina Kaufmann (eds.). The Art of C.G. Jung. Tr. Paul David Young and Christopher John Murray. New York / London: W. W. Norton.

Jensen, Robin M. 2012. Baptismal Imagery in Early Christianity: Ritual, 
Visual, and Theological Dimensions. Grand Rapids: Baker Academic.

. 1993. 'What are Pagan River Gods Doing in Scenes of Jesus' Baptism?' Bible Review 9:42-51.

Jerome. 2004. The Homilies of St Jerome, Vol. 2 (60-96). Tr. Sister Marie

Liguori Ewald, I.H.M. Washington, D.C.: Catholic University of American Press.

Jung, C.G. [1932]. 'Hans Schmid-Guisan: In Memoriam'. Collected Works of C.G. Jung. vol. 18, §§1713-1715 (pp. 760-61).

- 1925. Introduction to Jungian Psychology: Notes of the Seminar on Analytical Psychology Given in 1925. Rev. ed. Intro. S. Shamdasani; Princeton, NJ: Princeton University Press, 2012.

- 1932a. Psychologie of Kundalini Yoga: Notes of the Seminar Given in 1932. Ed. S. Shamdasani. Princeton: Princeton University Press, 1999.

. [1950]. 'On Occultism,' Fwd. to Moser: 'Spuk: Irrglaube oder Wahrglaube?’ Collected Works of C.G. Jung. vol. 18, §§757-763.

—. 2009. The Red Book: Liber Novus. Ed. S. Shamdasani. Tr. M.Kyburtz, J. Peck, \& S. Shamdasani. New York and London: W. W. Norton.

Jung, Carl G. \& John Freeman. 1959. 'The "Face to Face" Interview with John Freeman, BBC television, Oct. 22, 1959.' In William McGuire and R. F. C. Hull (eds.). C.G. Jung Speaking: Interviews and Encounters. Princeton: Princeton University Press, 1987.

Jung, Carl G. \& Aniela Jaffé. 2013. Erinnerungen, Träume, Gedanken. [Mannheim], Germany: Patmos.

- 1965. Memories, Dreams, Reflections Rev. ed. Tr. R. \& C. Winston. New York: Vintage Books.

Kerr, John. 1993. A Most Dangerous Method: The Story of Jung, Freud, and Sabina Spielrein. New York: Alfred A. Knopf.

Kirsh, Thomas B. 1996. 'Obituary Notice: C.A. Meier (1905-1995).' Journal of Analytical Psychology 41 (2): 291-292.

Kostof, Spiro K. 1965. The Orthodox Baptistery of Ravenna. New Haven \& London: Yale University Press.

Lachman, Gary. 2010. Jung the Mystic: The Esoteric Dimensions of Carl Jung's Life and Teachings: A New Biography. New York: Jeremy P. 
Tarcher/Penguin.

Marchal, Michael H. 2016. 'The Interplay of Ritual and Art: The Dome Mosaic in the Neonian Baptistery of Ravenna,' Sacred Architecture 29: 22-25, 27-28.

McLynn, Frank. 1996. Carl Gustav Jung: A Biography. New York: A Thomas Dunne Book/St. Martin's Press.

McGuire, William. (Ed.) 1974. Freud-Jung Letters. Tr. R. Manheim \& R. F. C. Hull. Princeton: Princeton University Press.

Mehrtens, Susan E. 2012. Jung the Man: His Life Examined. Charlotte, VT: Eltanin.

Molton, Mary Dian. \& Sikes, Lucy Anne. 2011. Four Eternal Women: Toni Wolff Rivisited - A Study in Opposites. Carmel, CA: Fisher King Press.

Montanari, Giovanni. 2001. Mosaics, Worship, Culture: Religious Culture in the Mosaics of the Basilicas of Ravenna. Tr. Scuola Interpreti e Traduttori, Ravenna. Ravenna: Opera di Religione Diocesi di Ravenna.

Muratori, Lodovico. 1725. Rerum italicarum Scriptore 1(2): 567-572.

Noel, Daniel C. 1993. 'A View on Jung's Ravenna Vision,' Harvest: Journal of Jungian Studies 39: 159-163.

Ouspensky, Leonid. \& Lossky, Vladimir. 1982. The Meaning of Icons. Rev. ed. Tr. G.E.H. Palmer \& E. Kadloubovsky. Crestwood, NY: St Vladimir Seminary Press.

Owen, Lance S. 2015. Jung in Love: The Mysterium in Liber Novus. Los Angeles \& Salt Lake City: Gnostic Archive Books.

Ricci, Corrado. 1900. Ravenna. Bergamo: Institutio Italiano D'arti Grafiche.

Richter, Jean Paul. 1878. Die Mosaiken von Ravenna. Vienna: Wilhelm Braumüller.

Rossi, Girolamo. 1572. Historiarum Ravennatum libri decem. Venice: [Manutius(?)].

Schoolman, Edward M. 2016. Rediscovering Sainthood in Italy: Hagiography and the Late Antique Past in Medieval Ravenna. New York: Palgrave Macmillan.

Shamdasani, Sonu. 2005. Jung Stripped Bare: By His Biographers, Even. 
London \& New York: Routledge.

Tileston, Eleanor Boise. 1915. Eleanor Boies Tileston (1886-1912).

Privately Printed. Norwood, MA: The Norwood Press.

von Franz, Marie-Louise. 1992. Psyche and Matter. Fwd. Robert Hinshaw. Boston \& London: Shambala.

Wagner, George. (Producer), \& Susanne Wagner (Director \& Interviewer). 1991. Marie-Louise von Franz, Remembering Jung III-September 1979 [Motion Picture]. United States. C.G. Jung Institute of Los Angeles \& Bosustow Video.

Wharton, Annabel Jane. 1987. 'Ritual and Reconstructed Meaning: The Neonian Baptistery in Ravenna'. The Art Bulletin 69 (3):358-375. 